\title{
The Parkes Lecture* Heat and the testis
}

\author{
Brian P. Setchell \\ Department of Animal Science, University of Adelaide, Waite Campus, Glen Osmond, SA 5064, Australia; and Pediatric Endocrinology \\ Unit, Karolinska Hospital, S17176 Stockholm, Sweden
}

\begin{abstract}
The evidence for the lower temperature of the testes of many mammals is summarized, and the reasons suggested for the descent of the testes into a scrotum are discussed. Descriptions are given of the various techniques used for studying the effects of heat on the testis, whole body heating, local heating of the testes (by inducing cryptorchidism, scrotal insulation or immersion of the scrotum in a water bath), and heating of tissue or cell preparations in vitro. The effects of heat are discussed, effects on the testis (weight, histology, physiology, biochemistry and endocrinology), on the numbers and motility of spermatozoa in rete testis fluid and semen, on fertilizing ability of spermatozoa and on the subsequent development of the embryos produced when spermatozoa from heated testes are used to fertilize normal ova. The possible mechanisms for the damaging effects of heat are discussed, as well as the importance of heat-induced abnormalities in male reproduction in domestic animals and humans.
\end{abstract}

\section{Introduction}

All tissues are susceptible to damage by heat. However, the testes are unusual in that they are damaged by exposure to the temperatures normally found within the abdomen, although they originate within the abdominal cavity and in many mammals descend into a scrotum only during fetal or neonatal development. In some mammals, and in all birds and all other classes of animal, the testes remain within the abdomen, and body temperature is considerably higher in birds than in mammals. There was a suggestion that the testes of birds are cooler than the other abdominal organs because of the proximity of some of the airsacs, but this is no longer believed to be the case (Beaupré et al., 1997). There is abundant evidence that the scrotal testes of mammals in a thermoneutral environment are appreciably cooler than the body (see Setchell, 1978; Waites and Setchell, 1990), but this does not mean that they are kept at a constant lower temperature. Because of the countercurrent heat exchange function of the blood vessels in the spermatic cord, the testes are kept at a uniform temperature throughout, and at approximately the same temperature as the subcutaneous scrotal tissue (see Setchell et al., 1994a; Setchell and Mieusset, 1996). If the animal is placed in a hot environment and evaporation of sweat from the scrotal skin cannot keep the scrotal skin cool, then the testis warms up (see Setchell and Mieusset, 1996). There is an approximately linear relationship between air temperature and subcutaneous skin temperature in the scrota of rams exposed to field conditions in an Australian summer (Setchell et al., 1994b), and when air temperature exceeds $40^{\circ} \mathrm{C}$, scrotal

\footnotetext{
* This review is based on the Parkes Lecture given at the joint meeting of the Society for the Study of Fertility, British Fertility Society and British Andrology Society held at the University of York in July 1997.
}

temperature rises to values normally found in the abdomen, while rectal temperature shows only a small rise. In rats acclimatized to an environment of $35^{\circ} \mathrm{C}$, the intrascrotal temperature was similar to the deep body temperature of control animals, although the scrotal-body temperature difference was maintained (Sod-Moriah et al., 1974).

If a testis does not descend normally into the scrotum, it is described as cryptorchid and bilaterally cryptorchid individuals are invariably sterile, although enough androgens are secreted to ensure that they have male characteristics and behaviour. Spontaneous cryptorchidism is reasonably common in humans (Hutson et al., 1997), pigs and horses, but much less frequent in ruminants (Wensing and Colenbrander, 1986). It was suggested by Crew (1922) that the cryptorchid testis was 'aspermatic' because it was at a higher temperature. Subsequent studies showed that if a cryptorchid pig testis is artificially cooled, spermatogenesis resumes (Frankenhuis and Wensing, 1979). Likewise, spermatogenesis does not commence in the testes of rats made cryptorchid by cutting the gubernaculum at birth (Bergh and Damber, 1978). If the testes are returned to the abdomen at 17 days of age, spermatogenesis does not begin until the testis is returned to the scrotum (Karpe et al., 1981, 1984), and the longer the time that elapses before this is done, the greater is the long-term effect. Elephants and hyraxes normally retain their testes close to the kidneys, and testis temperature in these animals is similar to body temperature (see Setchell and Mieusset, 1996), without apparently impairing their ability to produce spermatozoa. In one species of tropical rodent, Zygodontomys brevicauda, the testes continue to produce spermatozoa when the testes are returned to the abdomen, even though there is a small reduction in testis weight (Bronson and Heideman, 1993). 
However, alternative means of cooling abdominal testes appear to have evolved in Cetaceae, in which cool venous blood from the tail and dorsal fin is carried into the abdominal cavity in veins that lie interspersed among the arteries running to the testes (Rommel et al., 1992). Although the full physiological significance of this arrangement has not been determined, it does appear that tissues in the vicinity of these veins are at a lower temperature than other abdominal organs (Rommel et al., 1994; Pabst et al.,1995). In seals, the testes are outside the body cavity, but under a thick layer of blubber. Nevertheless, they too are considerably cooler than the abdominal cavity (Bryden, 1967; Blix et al., 1983), again because venous blood from the extremities is carried close to the testes and their arterial supply (Rommel et al., 1995). Therefore, although a few mammals appear to be able to produce spermatozoa in testes at body temperature, evolution does appear to have taken several routes to cooling the testes in most members of this class.

It is still a mystery why the testes of most mammals appear to need a lower temperature for normal function. Various suggestions have been made. It was thought (Ehrenberg et al., 1957) that the lower temperature might have the effect of reducing the higher mutation rate in males, but this appears to be due to a substantially lower mutation rate in the genes on the $\mathrm{X}$ chromosome than on the autosomes, and because there are so many more genes on the $X$ chromosome than on the $Y$, this lowers the mean rate for the $X X$ females (McVean and Hurst, 1997). Furthermore, it has recently been suggested that the higher mutation rate in males is important as a source of genetic novelty and it has been shown that there is also a higher mutation rate in genes on the $\mathrm{Z}$ chromosome than in those on the $\mathrm{W}$ chromosome in birds. Male birds are $\mathrm{ZZ}$, and the higher mutation rate in males is therefore more likely to be due to the greater number of cell divisions leading to the formation of spermatozoa than eggs (Ellegren and Fridolfsson, 1997). The lower temperature of the testis would presumably lead to a lower metabolic rate, although it is not clear why this should be an advantage. Various other suggestions for the evolution of the scrotum have been made, including that the scrotum developed as a form of sexual decoration (Portmann, 1952, but cf Ruibal, 1957; Cowles, 1965), that testicular descent decreases blood supply to maturing germ cells, so that the mitochondria enhance their enzymatic machinery for oxidative metabolism, resulting in increased aerobic fitness which is an advantage in interejaculate competition (Freeman, 1990) and even that the testes migrate out of the abdominal cavity in species that leap around most (Chance, 1996).

\section{Techniques for studying the effects of heat on the testis}

\section{Whole body heating}

In one sense the most physiological way of studying the effects of heat on the testis is to expose the whole animal to a hot environment. However, this involves two complicating factors. First, the body reacts to heat stress in a variety of ways, and there are significant physiological, metabolic and endocrinological changes that could affect the testis indirectly. Second, the ability of the scrotal skin to produce sweat can be influenced by the prior exposure of the animal to heat, and therefore for a given heat exposure, the temperature to which the testis is exposed may be quite different. Rams studied at the end of summer have much greater capacity for scrotal sweat production and hence testis cooling, than the same animals in winter (Waites and Voglmayr, 1963), and rams of two different strains, which had much different sensitivities to whole body heating, showed the same changes in semen characteristics and fertility when their testes were exposed directly to the same heat load (Fowler, 1968). Testes of rats kept at $35^{\circ} \mathrm{C}$ from weaning to 100 days old or for at least 30 days were no smaller than those of controls kept at 22 or $21^{\circ} \mathrm{C}$, although body weight and the weights of many other organs were reduced (Ray et al., 1968; Magal et al., 1981). Similarly, in a strain of mice that had been bred for many generations at $33^{\circ} \mathrm{C}$, a temperature normally causing appreciable infertility in this species unless they are exposed from weaning (Pennycuik, 1967), the testes were no smaller than those of animals of a similar genetic background kept at $21^{\circ} \mathrm{C}$, and were no more resistant to local heating of the testes than were those of control mice (van Zelst et al., 1995). This finding suggests that the heat-adapted animals had simply developed more efficient mechanisms for cooling their testes.

\section{Local heating of the testes}

Local heating of the testes has usually been achieved in one of three ways, induced cryptorchidism, scrotal insulation or short-term heating, usually by immersion in a water bath. Cryptorchidism can be produced easily in adult rodents (Piana and Savarese, 1891; Nelson, 1951; Clegg, 1960, 1963; Niemi and Kormano, 1965; Davis and Firlit, 1966; Meistrich et al., 1973; Risbridger et al., 1981; Sharpe, 1983; Fujisawa et al., 1988; Yin et al., 1997) and rabbits (Fukui, 1923b; Plöen, 1972, 1973a,b), because the inguinal canal remains patent and sufficiently large for the testis to be pushed up into the abdominal cavity. The testis must be held there, either by suturing it to the abdominal wall, or by closing the inguinal canal and in many cases the gubernaculum is cut. This technique exposes the testis to abdominal temperature, and the testis can be returned to the scrotum after a suitable interval. However, in many studies, the testis is left in the abdominal cavity until the selected observations are made. Cryptorchidism has also been produced in dogs (Griffiths, 1893), sheep (Moore and Oslund, 1924; Skinner and Rowson, 1968; Hochereau-de Reviers et al., 1979; Barenton et al., 1982; Lunstra and Schanbacher, 1988) and wallabies (Setchell and Thorburn, 1970), although in these animals the inguinal canal though patent is not large enough for the testis to pass through without surgical intervention. By making only one testis cryptorchid, the other testis of the same animal can be used as a control, and this also minimizes, but does not always eliminate, changes in peripheral hormone concentrations. Cryptorchidism can also be induced in newborn rats by cutting the gubernaculum (Bergh et al., 1978), or in immature 
animals before the testes have descended (Karpe et al., 1981, 1984). Cryptorchidism can be induced by treating pregnant females with the anti-androgen, flutamide, although not all male offspring are affected (Husmann and McPhaul, 1991; Spencer et al., 1991; van der Schoot, 1992) or with oestrogens (Rafjer and Walsh, 1977; Rajfer, 1982), although this treatment is more effective in mice than in rats (cf Hutson et al., 1990 and Boylan, 1978). The temperature of the testis can also be raised towards body temperature in sheep by shortening the scrotum, thereby pushing the testes up against the body wall (Thwaites et al., 1982; Sanford et al., 1988).

The testes can also be heated by insulating the scrotum, a technique that is very convenient in rams (Glover, 1955, 1956; Byers and Glover, 1984; Mieusset et al., 1992a), bulls (Ross and Entwistle, 1979; Prabhakar et al., 1990; Sidibe et al., 1992; Karabinus et al., 1997), stallions (Freidman et al., 1991) and boars (Malmgren, 1989, 1990), and the insulation can be continuous or intermittent, for example 8,12 or $16 \mathrm{~h}$ per $24 \mathrm{~h}$ (Mieusset et al., 1991, 1992a); insulation for only $8 \mathrm{~h}$ per day can eventually produce effects on spermatogenesis. Effects can even be produced by insulating only the neck of the scrotum in bulls (Kastelic et al., 1996). Humans can be trained to raise their testis temperature by $2-3^{\circ}$ for up to $30 \mathrm{~min}$ each day by biofeedback training (French et al., 1973), and testis temperature can also be raised by holding the testes against the perineal region with specially designed underclothing (Rock and Robinson, 1965; Robinson and Rock, 1967; Rock et al., 1968; Mieusset et al., 1985, 1987a,b ). Heat can also be applied by lamps, microwave or ultrasound (Fukui, 1923a, 1923-4; Imig et al., 1948; Fahim et al., 1975; Dumontier et al., 1977).

However, the most precise way of exposing a testis to an increased temperature for a short time is to immerse the scrotum in a water bath at the chosen temperature, usually with the animals anaesthetized or sedated. This technique has been used in rats (Steinberger and Dixon, 1959; Collins and Lacy, 1969; Chowdhury and Steinberger, 1964, 1970; Main et al., 1978; Jegou et al., 1984; Galil and Setchell, 1988a,b; Setchell et al., 1996), guinea-pigs (Moore, 1924a,b; Young, 1927), mice (Hand et al., 1979; Reid et al., 1981; Marigold et al., 1985; De Vita et al., 1990; Gasinska and Hill, 1990; van Zelst et al., 1995; Sailer et al., 1997; Setchell et al., 1998) and rams (Setchell et al., 1991; Mieusset et al., 1992b). By pushing one testis back into the abdomen and retaining it there during the heating, unilateral effects can be studied (Galil and Setchell, 1988 b). In rams, the scrotum can be enclosed in a small chamber, through which heated air can be circulated while heated water is pumped through tubing in the walls (Waites and Setchell, 1964; Fowler, 1968).

\section{Heating in vitro}

A few studies have examined the effects of heating the testis or testicular cells in vitro. Some have used isolated perfused testes (VanDemark and Ewing, 1963; Linzell and Setchell, 1969), whereas others have studied the effects of increased temperatures on incubated decapsulated testes (Biggiogera et al., 1996), segments of seminiferous tubules
(Parvinen et al., 1992; Cataldo et al., 1997) or on isolated testicular cells or a Sertoli cell line (Zakeri et al., 1990; Clark and Griswold, 1997).

\section{Actions of heat on the testes}

The actions of heat on the testis can be direct on specific cell types within the testis, but there are also indirect effects, resulting from the cellular changes occurring in the testis caused by the heating. While the latter are important in considering the effects of germ cells on the Sertoli and Leydig cells, in this review, attention will be mainly directed to the direct effects of heat. These effects can be demonstrated at five levels, effects on the testis itself, effects on the numbers, structure or motility of spermatozoa leaving the testis in rete testis fluid or those in semen, the fertilizing ability of those spermatozoa even when apparently normal in appearance and motility, and finally the development of the embryos resulting from in vivo or in vitro fertilization with spermatozoa from heat-treated males in normal females.

\section{Effects on testis}

Weight. One of the more obvious effects of acute or chronic exposure of the testes to heat is a reduction in testis weight. This occurs between 1 and 2 days after a single exposure of the testes of rats, and testis weight has reached a minimum of about $40 \%$ of control between 7 and 28 days after treatment at either $41^{\circ} \mathrm{C}$ for $60 \mathrm{~min}$ or $43^{\circ} \mathrm{C}$ for $30 \mathrm{~min}$. Thereafter there is a return towards normal weight, but testis weight can still be below the control value for at least 63 days after a single heating (Setchell and Waites, 1972; Fridd et al., 1975; Main et al., 1978; Bartlett and Sharpe, 1987; Galil and Setchell, 1988b; McLaren et al., 1994; Setchell et al., 1996). Exposure of the testes of rats 7 times at 6 week intervals to $43.5^{\circ} \mathrm{C}$ for $20 \mathrm{~min}$ produced a decrease in testis weight of about $40 \%$, which was maintained for at least 24 weeks after the last exposure (Bowler, 1972). If a rat is made cryptorchid, testis weight does not change in the first $24 \mathrm{~h}$ (Setchell, 1970 and unpublished results; Bergh and Damber, 1984), but has fallen below control values by the second day in young rats (Shikone et al., 1994) and by 5-7 days in adult rats (Clegg, 1963; Fujisawa et al., 1988). Exposure of unacclimatized mice to an environment of $35^{\circ} \mathrm{C}$ leads to a fall in testis weight within 4 days (Meistrich et al., 1973). The reduction in testis weight after local heating is comparable in extent to that in rats (Hand et al., 1979; Marigold et al., 1985; Gasinska and Hill, 1990; Van Zelst et al., 1995; Jannes et al., 1998); after exposure to $42^{\circ} \mathrm{C}$ for $30 \mathrm{~min}$, there is no change after 1 day, but a fall of almost 50\% after 3 days (Sailer et al., 1997). However, the decrease in testis weight after cryptorchidism was slower than that in rats, with significant difference of about $25 \%$ from control only becoming evident after 7 days (Meistrich et al., 1973; Yin et al., 1998). In rams, a decrease of about $50 \%$ in testis weight occurred 21 days after the testes had been exposed to $42^{\circ} \mathrm{C}$ for $45 \mathrm{~min}$ (Setchell et al., 1991; Hochereaude Reviers, 1993) and exposure of rams to a hot environment for 14 days caused a reduction in testis weight to about $70 \%$ 
of control values (Gomes et al., 1971). Cryptorchid testes weigh less than $20 \%$ of normal testes (Hochereau-de Reviers, 1979; Barenton et al., 1982; Lunstra and Schanbacher, 1988) and testes from short-scrotum animals are also much smaller than those of normal animals (Sanford et al., 1993).

Histology. Histological changes were observed in heated and cryptorchid testes by many early investigators (Moore, 1924a,b; Fukui, 1923a, 1923 /4; Moore and Oslund, 1924), and changes in spermatocytes could be detected on the day after exposure to heat (Young, 1927). Later studies showed that increased numbers of abnormal pachytene spermatocytes could be detected as early as $1 \mathrm{~h}$ after the testes of rats had been exposed to $43^{\circ} \mathrm{C}$ for $15 \mathrm{~min}$, although at that time there were no obvious effects on the number of spermatogonia (Chowdhury and Steinberger, 1964, 1970). Dye chromophilia could also be seen in pachytene and diplotene spermatocytes as early as $1 \mathrm{~h}$ after heating the testes to $42^{\circ} \mathrm{C}$ for $30 \mathrm{~min}$, and by $2 \mathrm{~h}$, there were changes in acid phosphatase and aminopeptidase in these cells (Blackshaw and Hamilton, 1970). In rats acclimatized for 3 months to an environment of $35^{\circ} \mathrm{C}$, spermatogenesis was severely affected in about $20 \%$ of tubular cross-sections, whereas the remainder appeared normal (Sod-Moriah et al., 1974). In rams, greater numbers of degenerating pachytene spermatocytes were found $12 \mathrm{~h}$ after a $150 \mathrm{~min}$ exposure of the testes to $40^{\circ} \mathrm{C}$ (Waites and Ortavant, 1968). There is one report that in pigs exposed to a hot environment for 90 days, the spermatids, but not pachytene spermatocytes, are reduced in number (Wettemann and Desjardins, 1979), but a later study using scrotal insulation for $100 \mathrm{~h}$ showed that both pachytene spermatocytes and early spermatids were affected and reduced in number by the end of the insulation period (Malmgren and Larsson, 1989). The sensitivity of the pachytene spermatocytes was also found in mice, as judged from the numbers of elongated spermatid nuclei, which could be counted in homogenates of testes, taken 14 days after heating for $30 \mathrm{~min}$ at $43^{\circ} \mathrm{C}$ (Gasinska and Hill, 1990). This result was confirmed using flow cytometry to assess the numbers of haploid cells (De Vita et al., 1990), and although there was no change after 1 day, a fall in the percentage of haploid cells could be detected 3 days after exposure to $42^{\circ} \mathrm{C}$ for $60 \mathrm{~min}$ (Sailer et al., 1997). The numbers of spermatids and spermatozoa in fragments of human testes were lower when they were cultured at $37^{\circ} \mathrm{C}$, rather than $31^{\circ} \mathrm{C}$, whereas the numbers of spermatogonia and spermatocytes were not affected (Nakamura et al., 1987). Pachytene spermatocytes and young spermatids also appear to be the first cells to be affected in experimental cryptorchidism in rats (Davis and Firlit, 1966; Parvinen, 1973; Blackshaw and Massey, 1978) and rabbits, in which degenerating cells were found after $24 \mathrm{~h}$ (Plöen, 1973a); however, there were also changes at this time in spermatids (Plöen, 1972), and these became more pronounced later, even though the testis had been returned to the scrotum (Plöen, 1973b). In immature (Shikone et al., 1994) and in mature rats (Henriksen et al., 1995) and mature mice (Yin et al., 1997), cryptorchidism induces increased apoptosis of germ cells, which in the adult animals mainly involved spermatocytes and round spermatids. However, there is one report that local heating of the testes appears to cause increased apoptosis of spermatogonia (Allan et al., 1987). Subsequent studies by Swerdloff et al. (1998) do not support this, and in their studies, the increased apoptosis seems to involve mostly spermatocytes (Lue et al., 1998), but at a different stage of the cycle from that seen after gonadotrophin withdrawal (Sinha Hikim et al., 1995, 1997).

However, even though it is now generally agreed that the pachytene spermatocytes and spermatids are the cells most easily affected, if the degree of heat exposure is increased, either by increasing the temperature or the time of exposure, then there are also effects on other cell types. Collins and Lacy (1969), in a study involving a range of times of exposure of rat testes to $43^{\circ} \mathrm{C}$, suggested that there were two "critical periods', beyond which cells in heated testes could not proceed. As the time of exposure was increased, a third critical period was revealed, and eventually, all these periods merged into one. Other authors (Idänpään-Heikkilä, 1966) reported effects on Sertoli cells and the basement membrane of the seminiferous tubules. In rams, as well as the effects on spermatocytes, there was also an increase in the numbers of dividing B-spermatogonia, which subsequently die (Waites and Ortavant, 1968). Counts of spermatid nuclei (Gasinska and Hill, 1990) or determining the percentage of haploid cells by flow cytometry (De Vita et al., 1990; Sailer et al., 1997) after 28 days indicated that the differentiating spermatogonia are less sensitive than the pachytene spermatocytes, but are still affected by the heating. The failure of the testis weight to return completely to control values even after more than 60 days, or after 24 weeks after repeated heating, which has already been mentioned, also suggests that the spermatogonia are not unaffected and Reid et al. (1981) showed that heating of the testis exacerbated the effects of radiation on the spermatogonia, as judged by repopulation of tubules 35 days after treatment.

It is also generally assumed that the timing of spermatogenesis is constant for any given species, but there is one study that suggests that the duration of the spermatogenic cycle in mice is decreased slightly in cryptorchid testes, and in animals kept at $32^{\circ} \mathrm{C}$ (Meistrich et al., 1973). Incubating segments of seminiferous tubules at $37^{\circ} \mathrm{C}$ rather than at $32^{\circ} \mathrm{C}$ appeared to speed up the transition from one stage of spermatogenesis to the next (Parvinen et al., 1992).

It has also been reported that there was an increased incidence of $X-Y$ dissociation in primary spermatocytes in diakinesis-metaphase after exposure of mice to an environment of $35^{\circ} \mathrm{C}$ for 2,3 or 5 days, an effect which reached a peak 5 days after the end of the heat stress; this would indicate that the primary effect was again on spermatocytes at the pachytene stage (Garriott and Chisman, 1980; Waldbieser and Chisman, 1986). The increased X-Y dissociation after exposure of cool-adapted mice to an environment of $33^{\circ} \mathrm{C}$ was subsequently confirmed, and it was also shown that the same effect could be produced by local heating of the testes of mice and rats (Van Zelst $e t$ al., 1995).

Physiology. Most experiments, using a variety of techniques for measuring either total or capillary blood flow through the testis, indicate that blood flow through the testis 
does not increase until testis temperature reaches values well above body temperature (Waites and Setchell, 1964; Setchell et al., 1966; Waites et al., 1973; Godinho and Setchell, 1975; Damber and Janson, 1978; Setchell et al., 1995), except in marsupials (Setchell and Thorburn, 1969) although there is one study in anaesthetized rams which suggests that total blood flow does increase as the temperature is raised from the normal scrotal temperature of $33^{\circ} \mathrm{C}$ to $36^{\circ} \mathrm{C}$, but there is no further increase as the temperature was raised to $39^{\circ} \mathrm{C}$ (Mieusset et al., 1992b). In another experiment in rams exposed to an environment of $32^{\circ} \mathrm{C}$ for 7 days, blood flow through the testis showed an initial increase after $24 \mathrm{~h}$, followed by a return to normal flow at 3 days, and then reduced to about half the normal blood flow; similar results were found when the testes were heated by enclosing the scrotum in an electric heating pad which raised the temperature of the testis to about $39^{\circ} \mathrm{C}$ (Dutt et al, 1977). The failure to detect consistently any changes in flow when the temperature of the testis is increased contrast with studies in other tissues, where flow is very sensitive to increases in temperature, and in experiments where blood flow was measured at various times after exposure of the testes to heat. Under these circumstances, as the weight of the testis decreased, the blood flow per testis decreased in proportion, that is to say blood flow per unit weight of testis remained about the same (Galil and Setchell, 1988b; Setchell et al, 1991).

However, one obvious change that is seen involves the pattern of blood flow as the temperature of the testis is changed. Vasomotion, the rhythmical fluctuations in flow with a frequency of about 10 per min unrelated to heart or respiration rate decreased in amplitude and increased in frequency as the temperature was raised, and finally disappeared; as the temperature was reduced again, vasomotion reappeared, amplitude increased and frequency decreased, until at temperatures below normal, there were very slow (about 6 per min) fluctuations with an amplitude of as much as $50 \%$ of average flow (Setchell et al., 1995). The significance of these changes, or indeed the importance of vasomotion in the normal function of the testis, are not understood. However, it has been suggested that the fluctuations in flow in individual capillaries associated with vasomotion might be involved in determining rates of fluid filtration and reabsorption in tissues, and therefore it is a pity that no measurements appear to have been made on vascular permeability in the testis at various temperatures to either small or large molecules.

The blood-testis barrier, which limits the penetration of many substances into the seminiferous tubules, is only marginally affected by temperature. Flow of fluid from the rete testis, which depends on the integrity of the barrier, is reduced during heating in rams (Linzell and Setchell, 1969; Setchell et al, 1971) but not in rats (Main and Waites, 1977), and the composition of the fluid was unaffected at the time of heating or subsequently (see also Setchell et al., 1996). However, the entry rates for $\mathrm{K}^{+}, \mathrm{Na}^{+}$, lysine and some of the more slowly penetrating steroids (not testosterone) were increased during heating, although the entry of albumin was unaffected (Main and Waites, 1977). In cryptorchid rat testes, lanthanum salts were excluded from the tubules, just as they were in normal adult testes, while penetration to the lumen was found in testes from prepubertal rats (Hagenäs et al., 1977). However, some slight deterioration of the barrier 7 days after the testes were made cryptorchid could be demonstrated by measuring the rate of entry of radioactive inulin into luminal fluid collected from the seminiferous tubules by micropuncture (Turner et al., 1982).

Biochemistry. The uptake of oxygen in vivo is significantly increased during heating of the testes of rams, but with little change in the uptake of glucose or the production of lactate (Waites and Setchell, 1964; Free and VanDemark, 1968). Pieces of seminiferous tubule incubated in vitro secreted less lactate than do tubules from scrotal testes (Bergh et al, 1987). The rat testis has been shown to contain the glucose transporters GLUT 2 and 3 in appreciable amounts, and GLUT 2 is increased and GLUT 3 reduced in testes that had been cryptorchid for 10, 20 or 30 days (Farooqui et al., 1997). However, these studies make no reference to other reports which showed that the endothelial cells of the testis contain GLUT 1, the glucose transporter usually associated with the blood-brain barrier (Holash et al., 1993).

The incorporation of labelled amino acids into protein is decreased when isolated spermatids are incubated at $38^{\circ} \mathrm{C}$ instead of $34^{\circ} \mathrm{C}$ (Nakamura et al, 1978; Nakamura and Hall, 1980). When seminiferous tubules were isolated from rats whose testes had been heated to $43^{\circ} \mathrm{C}$ for $30 \mathrm{~min} 4 \mathrm{~h}$ earlier, there was greater incorporation of labelled methionine into secreted proteins at stages VI-VIII, with no change with tubules at stages II-V and IX-XII. In contrast, with tubules isolated $24 \mathrm{~h}$ after heating, incorporation was reduced into tubules at stages VI-VIII, with a lesser effect for tubules at stage IX-XII and no effect for those at stages II-V. Similar changes were seen in intracellular proteins, and reproducible decreases were seen in the secretion of three androgenregulated proteins (McLaren et al., 1994). The translation of mRNA for histone $\mathrm{H} 1 \mathrm{t}$ in pachytene spermatocytes was reduced in tubules incubated at $37^{\circ} \mathrm{C}, 42.5^{\circ} \mathrm{C}$ or $44^{\circ} \mathrm{C}$, whereas only minimal effects were seen on the translation of mRNA for transition proteins 1 and 2 in elongated spermatids; incremental reductions were also seen in the size of the polysomes translating $\mathrm{H} 1 \mathrm{t}$ mRNA and sulfated glycoprotein 2 (also known as clusterin) in Sertoli cells, while the size and proportion of polysomal protamine 2 mRNA in elongated spermatids were unaffected (Cataldo et al., 1997). Culturing rat or mouse Sertoli cells for $48 \mathrm{~h}$ at $41^{\circ} \mathrm{C}$ led to an increase in clusterin mRNA after $12 \mathrm{~h}$, i.e. appreciably later than the increases seen in heat-stressed human epithelioid cancer cells (Clark and Griswold, 1997).

Heat has a differential effect on the two haeme oxygenase isozymes present in the rat testis, $\mathrm{HO}-2$, which is normally present in greater amounts is unaffected, whereas $\mathrm{HO}$ 1 ,which is normally present in only low concentrations in Sertoli cells, and could not be detected in Leydig cells, shows intense immunoreactivity in both Sertoli and Leydig cells $6 \mathrm{~h}$ after heating to $42^{\circ} \mathrm{C}$ for $20 \mathrm{~min}$. The mRNA for HO- 1 shows an increase in testes within $1 \mathrm{~h}$ after heating (Ewing and Maines, 1995). Use of a cDNA probe showed that mRNA for HO-1 could be detected in germ cells as well as in somatic cells in the testis, and while heat stress did not change the pattern of distribution among the cell types, it caused a 
distortion of the nuclear pattern and diffusion of the transcript signal in the cells (Maines and Ewing, 1996).

The expression of the mRNA for a recently identified coldinducible RNA-binding protein in cultured mouse germ cells was reduced when culture temperature was raised from $32^{\circ} \mathrm{C}$ to $37^{\circ} \mathrm{C}$, and when mouse testes were heated, either by making them cryptorchid or immersing in a water bath at $42^{\circ} \mathrm{C}$ for $30 \mathrm{~min}$, expression was reduced within $6 \mathrm{~h}$ of either treatment (Nishiyama et al., 1998).

DNA synthesis in testicular germ cells in isolated seminiferous tubules is much more sensitive to heat than are protein or RNA synthesis (Nishimune and Komatsu, 1972), and later studies have shown that the activity of DNA polymerase beta decreased by $43 \%$ within 5 days of the testis being made cryptorchid and the activity of DNA polymerase gamma was even more sensitive ( $46 \%$ decrease after 3 days), whereas the activities of DNA polymerase alpha and topoisomerase I were unaffected (Fujisawa et al., 1988). When minced testis tissue was incubated at $31^{\circ} \mathrm{C}$ or $37^{\circ} \mathrm{C}$, the activities of all four enzymes were lower at $37^{\circ} \mathrm{C}$ than at $31^{\circ} \mathrm{C}$ (Fujisawa et al., 1997). Incorporation of thymidine into DNA by human testis fragments was maximal at $31^{\circ} \mathrm{C}$, whereas uridine incorporation into RNA and leucine incorporation into protein were maximal at $37^{\circ} \mathrm{C}$ (Nakamura et al., 1988). One of the most marked changes seen after cryptorchidism involved an extractable enzyme system from mouse spermatocytes capable of catalysing recombination in vitro; the activity of this system increases 400 -fold between preleptotene and mid-pachytene stages under normal conditions, and is decreased 50-fold after the testes had been cryptorchid for $24 \mathrm{~h}$, and fell even further (350-fold) by the fifth day (Hotta et al., 1988). Unfortunately, shorter times were not examined, but it would be interesting to see how quickly a change in this system could be noticed.

A number of other enzymes in the testis appear to be affected by heat, but again it is is not always clear whether this is a direct effect, or a result of the cellular changes within the tissue. For example, uridine kinase, which is normally present in highest amounts in peritubular cells and primary spermatocytes, with less in Sertoli cells, spermatids and spermatozoa in that order, is unchanged after 1 day, but increased after 3 days, and peaks at 12 days after the induction of cryptorchidism in adult rats. Cryptorchidism induced at 17 days of age prevents the normal increase seen as the animal matures (Haugen et al, 1988). Similarly, adenylate cyclase and protein carboxyl methylase do not increase normally if the testis is made cryptorchid at 17 days, but do increase to normal values after orchidopexy when the rats were 34 days old (Jahnsen et al., 1986). The enzyme cholesteryl ester hydrolase which is present mainly in Sertoli cells in rats is reduced in testes made cryptorchid 24 h earlier (Hoffmann et al., 1989).

Insulin-like growth factor I (IGF-I) receptors, which are normally present on primary spermatocytes, Sertoli cells and Leydig cells usually decrease as the rats mature, but if the animals are made cryptorchid at 3 days old, IGF-I receptors increase as the animal ages, mainly due to very large numbers under these conditions in Sertoli cells (Antich et al., 1995).

Temperature may also affect the permeability of the plasma membranes and lysosomes of germinal cells in the testis, as shown by increased leakage of their cellular contents and increased staining with trypan blue during incubation in vitro (Lee and Fritz, 1972; Lee, 1974).

At least some of these changes may result from impaired detoxification of reactive oxygen at the higher temperatures. A reduction in superoxide dismutase and catalase activities were seen 1 day after the testis was made cryptorchid, although the level of oxidative stress, as measured by the appearance of conjugated diene double bonds in polyunsaturated fatty acids was normal after 1 and 3 days, and only increased on day 7 , at which time GSH peroxidase, GSH transferase and hexose monophosphate shunt activities were also increased. Superoxide dismutase activity was reduced by incubating normal decapsulated testes at $37^{\circ} \mathrm{C}$ or $40^{\circ} \mathrm{C}$, whereas the enzyme from liver and other enzymes from the testis were unaffected (Ahotupa and Huhtaniemi, 1992). Later studies showed that the abdominal testis before normal descent also demonstrates a higher degree of lipid peroxidation, and the normal decrease is prevented if the testis is made cryptorchid; under these conditions, the oxidative stress in the cryptorchid testis cannot be explained by inactivation of antioxidant enzymes (Peltola et al., 1995).

There has been a great deal of interest recently in heatshock proteins, which are synthesized by many cell types in response to stress, particularly heat stress. However, in the testis, which contains a high content of these proteins, the major proteins appear to be concerned with development of germ cells, and are not heat inducible. Spermatocytes contain hsp 70-2 and spermatids contain hsp 70t, and neither of these is heat-inducible (see Dix, 1997 for review). However, there is some evidence that some other heat shock proteins (HSI 36 and HSID 74) are formed in greater amounts at higher temperatures (Lemaire and Henlein, 1991). The expression of hsp 70 related gene in the rat testis is not altered in testes that have been cryptorchid for 1 day, although there are decreases at 2, 3 and 6 days (Krawczyk et al., 1987). The expression of hsp 70 was not increased in rats subjected to whole body hyperthermia $\left(42.5^{\circ} \mathrm{C}\right)$ for $45 \mathrm{~min}$, although there was a marked increase in livers from these animals (Krawczyk et al., 1988). However, this may be because the principal hsp 70 in the testis is hsp 70-2, which is not heat inducible, whereas hsp 72 is induced in somatic cells in the testis by heat (Zakeri et al., 1990). There is also evidence for an increased synthesis of hsp 70, but not hsp 70-2 (named P70 by these authors) in mouse pachytene spermatocytes when they are subjected to a temperature of $42.5^{\circ} \mathrm{C}$ for $10 \mathrm{~min}$ in vitro (Allen et al., 1988a,b). Others have found evidence for induction of two other heat shock proteins, HSP 90 and HSP 27 in the testis in response to heat (decapulated testes exposed to $42^{\circ} \mathrm{C}$ for $1 \mathrm{~h}$ in vitro), and also relocation of these proteins to the nucleus. There was also a sharp increase in the labelling of the HSPs in the chromatoid body of round spermatids after hyperthermic treatment (Biggiogera et al., 1996). It has also been shown that mixed germ cell preparations and isolated pachytene spermatocytes from mouse testes exhibited a lower activation temperature for Heat Shock Factor 1 (HSF 1) than did liver cells, and this activation leads to increased expression of hsp 72 in germ cells (Sarge, 1995; Sarge et al., 1995). Another heat shock 
factor, HSF-2, is also present in mouse testis, but this appears to be involved in the regulation of the non-inducible hsp 70.2 gene (Sarge et al., 1994).

Another protein that appears to be involved in meiosis is p53, and this gene is associated with the nuclear envelope, and particularly of pachytene spermatocytes (Almon et al., 1993; Schwartz et al., 1993; Yin et al., 1997). Mice deficient in this gene exhibit a giant-cell degenerative syndrome in the testis (Rotter et al., 1993) and temperature-mediated germ cell loss in the testis is associated with altered expression of p53 (Socher et al., 1997). However, p53-deficient mice still showed a fall in testis weight after cryptorchidism, although the decrease was delayed from 7 days to 10 days (Yin et al., 1998).

Endocrine function. The effects of whole body heating on the testosterone concentrations in blood depend largely on how stressful the environment has been to the animal. Young male rats exposed for 3 to 5 weeks to a temperature of $33-35^{\circ} \mathrm{C}$ have lower body weights and serum testosterone concentrations, although testis weight is not affected (Bedrak et al., 1980). Similarly, bulls exposed to a hot environment for 7 weeks (Rhynes and Ewing, 1973) or 15 days (Minton et al., 1981) showed reductions in serum testosterone concentrations, although in the longer experiment, concentrations returned to normal with time and the response to GnRH infusion was normal. In rams, testosterone concentrations in testes and spermatic venous blood were reduced by 14 days exposure to an environment which varied between $28^{\circ} \mathrm{C}$ and $32^{\circ} \mathrm{C}$ each day (Gomes et al., 1971). In boars subjected to an environment at $35^{\circ} \mathrm{C}$ for $24 \mathrm{~h}$, there was no change in testosterone concentrations in blood, although the diurnal rhythm was lost (Stone and Seamark, 1984). Longer exposure times $\left(100 \mathrm{~h}\right.$ at $\left.35^{\circ} \mathrm{C}\right)$ caused a fall in testosterone concentrations, with an increase after the period in the climate room; blood cortisol concentrations were significantly increased only during the heat exposure (Larsson et al., 1983). Even longer exposures $\left(34.5^{\circ} \mathrm{C}\right.$ for $8 \mathrm{~h}$ and $31^{\circ} \mathrm{C}$ for the rest of the day for 14 days) caused a halving of blood testosterone concentrations (Wettemann and Desjardins, 1979).

Cryptorchidism caused serum testosterone concentrations to fall slightly or remain the same in rats, but $\mathrm{LH}$ concentrations rose, suggesting that the Leydig cells needed to be driven harder to achieve the same result (Keel and Abney, 1980; Amatyakul et al., 1971; Gupta et al., 1975; Risbridger et al., 1981; Jansz and Pomerantz, 1986). Earlier observations using the weight and composition of the androgen-responsive accessory glands as an index of androgen concentrations suggested that there was no fall in androgen secretion after cryptorchidism, although the evidence for a slight increase at later times seems rather equivocal (Clegg, 1960). However, in rats made unilaterally cryptorchid at birth, androgen concentrations in the cryptorchid testes were much lower than in scrotal testes (Bergh et al., 1984). In cryptorchid rams, testosterone concentrations in peripheral and spermatic vein blood were normal, but LH concentrations were increased, and there was a diminished response to injected LH (Hochereau-de Reviers et al., 1979; Barenton et al., 1982; Lunstra and
Schanbacher, 1988). Testosterone concentrations of shortscrotum rams were generally similar to those of intact animals (Tierney and Hallford, 1985), except when the testes were growing most rapidly during short-day periods (Sanford et al., 1993).

Scrotal insulation in bulls had little effect on blood testosterone or LH concentrations (Prabhakar et al., 1990; Sidibe et al., 1992). In rams, scrotal insulation for 28 days caused severe testicular degeneration, but after 7 days, mean testosterone concentrations in blood were unaffected, while LH concentrations were raised and there was an increase in the number and amplitude of LH pulses. After 14 days mean and basal concentrations of testosterone were lower and the testosterone peaks reduced in size, while $\mathrm{LH}$ peaks and mean LH were increased (Byers and Glover, 1984). The effect of scrotal insulation in boars on testosterone concentrations depended on the age of the animals used in the experiments; with mature animals, there was no change in testosterone concentrations for the first $24 \mathrm{~h}$ of a $100 \mathrm{~h}$ insulation, but thereafter, concentrations fell to almost half of control values. Oestradiol concentrations were also slightly reduced at the same time, but while testosterone concentrations returned to normal after 3 days, oestradiol concentrations remained low for at least 6 days. Oestrone sulphate concentrations responded in a similar way to those of testosterone. In immature boars, neither testosterone nor oestradiol, nor oestrone sulphate concentrations was affected by scrotal insulation for $100 \mathrm{~h}$ (Malmgren, 1990).

Local heating of the testes of rats for $30 \mathrm{~min}$ to $43^{\circ} \mathrm{C}$ had no effect on testosterone concentrations in peripheral blood between 2 and 56 days after heating, although the response to LH or hCG was reduced (Damber et al., 1980; Galil and Setchell, 1988a). Between 7 and 35 days after heating, the concentration of testosterone in testicular venous blood was actually higher than control values, although because at that time blood flow was decreased, testosterone secretion was normal or only slightly reduced (Galil and Setchell, 1988b). Raising the temperature of the testis to $41^{\circ} \mathrm{C}$ or $43^{\circ} \mathrm{C}$ at the time of an $\mathrm{LH}$ injection caused a reduced response to $\mathrm{LH}$ in plasma and testis testosterone concentrations, while at a temperature of $37^{\circ} \mathrm{C}$, the response was not different from those of controls held at $33^{\circ} \mathrm{C}$ (Damber and Janson, 1978).

\section{Spermatozoa in rete testis fluid}

Two studies have examined the spermatozoa in rete testis fluid collected from testes that had been heated, one study was in rats (Setchell and Waites, 1972) and the other in rams (Setchell et al., 1971; Voglmayr et al., 1971). In rats, the concentration of spermatozoa in rete testis fluid began to decrease within 10 days after a single exposure of the testes to $41^{\circ} \mathrm{C}$ for 60 or $90 \mathrm{~min}$, and returned to normal at about 38 days; the fall was about 1000 -fold. In rams, the decrease occurred later, about 20 days after heating to $40^{\circ} \mathrm{C}$ for $3 \mathrm{~h}$, although the concentrations returned to normal at about the same time as in rats. There was also a decrease in the rate of flow of rete testis fluid in rams during the heating period, and there were changes in the metabolism and ultrastucture of the spermatozoa collected within 1- 4 days after heating. 
The fall in sperm concentration in rams was greater than in rats. The timing of the fall was consistent with a major effect on pachytene spermatocytes and early spermatids.

\section{Spermatozoa in semen}

Increase in body temperature in men by whole body heating (MacLeod and Hotchkiss, 1941), or local heating of the testes (Watanabe, 1959; Tokuyama, 1963) is followed by a decrease in sperm concentration in semen between 3 and 11 weeks later. After sauna baths (Procope, 1965; BrownWoodman et al., 1984), after local heating of the testes (Robinson et al., 1968) or after self-induced scrotal hyperthermia (French et al., 1973), there was also a fall in the number of spermatozoa, in some instances within 1 week after heating, but never earlier than that.

In bulls, whole body heating produced decreases in numbers and motility of spermatozoa, and a rise in abnormal and dead cells, also beginning 1 week or more after a single exposure, and persisting for between 40 and 60 days after the end of the heating (Casady et al., 1953; Skinner and Louw, 1966). In rams, decreases in motility and in the percentage of normal spermatozoa and, in some cases, numbers of spermatozoa occurred between 1 and 2 weeks after heat exposure, returning to normal after between 30 and 42 days (Dutt and Hamm, 1957; Moule and Waites, 1963; Smith, 1971). In boars, in a number of experiments, the number of spermatozoa was not affected, but motility and the percentage of normal spermatozoa fell between 1 and 6 weeks after the heat exposure; when the heating was for only a limited period, motility and the percentage of normal spermatozoa recovered after about 6 weeks (McNitt and First, 1970; Wettemann et al., 1976, 1979; Stone, 1981; Larsson and Einarsson, 1984; Malmgren and Larsson, 1984).

Local heating of bull testes by insulation also caused falls in motility and percentage of normal spermatozoa, beginning 12 to 14 days later, and lasting until day 26 to 90 , depending on the length of insulation. There were also decreases in sperm concentration in most experiments, beginning usually 1 to 2 weeks later than the changes in motility (Austin et al., 1961; Ross and Entwistle, 1979; Wildeus and Entwistle, 1986; Vogler et al., 1991, 1993; Karabinus et al., 1997). Even insulation of only of the neck of the scrotum produced similar effects (Kastelic et al., 1996). In rams, local heating of the testes or insulation of the scrotum caused similar changes in sperm motility and the percentage of normal spermatozoa, and if maintained continuously for a sufficient period, in the concentration of spermatozoa in semen; intermittent insulation often caused decreases in motility without any changes in the number of spermatozoa (Glover, 1955; Waites and Setchell, 1964; Braden and Mattner, 1970; Mieusset $e t$ al., 1992a). In pigs, insulation of the scrotum for $100 \mathrm{~h}$ had no effect on the number of spermatozoa, but motility and the percentage of normal spermatozoa decreased between 2 and 6 weeks afterwards (Malmgren, 1989). In stallions, insulation for 24 or $48 \mathrm{~h}$ produced falls in motility after only a few days, with the number of spermatozoa and the percentage of normal spermatozoa falling after about 10 days; recovery occurred at about 70 days (Freidman et al., 1991). In rats in which the accessory glands had been removed surgically so that the ejaculate could be liquefied with chymotrypsin, the number of spermatozoa in semen obtained by electroejaculation fell about 10 days after immersion of the testes in a water bath at $41^{\circ} \mathrm{C}$ for $27 \mathrm{~min}$ and remained low until about day 70 (Mauss, 1971). In mice whose testes had been heated to $40^{\circ} \mathrm{C}$ for $60 \mathrm{~min}$, the spermatozoa in the cauda epididymidis showed an increased percentage of abnormal forms from day 7 to day 35, and the structure of the sperm chromatin was abnormal, as judged by the susceptibility of the epididymal spermatozoa to in situ denaturation at low $\mathrm{pH}$, from day 3 to day 35 ; mice exposed to $42^{\circ} \mathrm{C}$ for $60 \mathrm{~min}$ had too few spermatozoa in the epididymis for measurements to be made (Sailer et al., 1997). Mice whose testes were heated to $42^{\circ} \mathrm{C}$ for $20 \mathrm{~min}$ still had spermatozoa in the epididymis 28 days later, but there were fewer than in controls, and motility was decreased (Jannes et al., 1998).

\section{Fertility and fertilization}

The effects of exposure to heat on the fertility of male animals has been known for a long time, although the effects vary widely between individual animals, and depend on the extent of acclimatization. Young (1927) found that of 19 male guinea-pigs whose testes were heated to the same extent, two continued to reproduce normally, but the other 17 showed various effects, ranging from temporary sterility lasting from 7 to 44 days after heating to permanent sterility in three individuals. Cunningham and Osborn (1929) heated the testes of rats with infra-red or hot air, and found that the animals were sterile between 16 and 82 days and 34 and 85 days, respectively, with a second sterile period following a short period of normal fertility lasting about 20 days. Elfving (1950) heated the testes of rats in a water bath at $44.3^{\circ} \mathrm{C}$ for 20 min, and found that all animals became sterile. In three, sterility was permanent, in the other 12 , the sterile period began between 10 and 20 days after heating and ended between 50 and 140 days after heating. Furthermore, he found with a small number of animals that the onset of the sterile period could be delayed by treatment with serum gonadotrophin (a crude preparation of $\mathrm{FSH}$ ), thyroid hormone or a low dose of testosterone; hCG or a large dose of testosterone was without effect. None of the treatments tried altered the time of restoration of normal fertility. In a later study with rats, the infertile period after heating the testes to $43^{\circ} \mathrm{C}$ for $30 \mathrm{~min}$ lasted from between 7 and 14 days after heating to between 49 and 56 days (Setchell et al., 1988). When the testes of mice were heated to $42^{\circ} \mathrm{C}$ for $20 \mathrm{~min}$, they remained fertile, but if the heating period was extended to 30 min, although they continued to mate at a normal rate, no pregnancies resulted between 10 days and 32 days with one male and 38 days with the other (Setchell et al., 1998). When mice were placed as adults in an environment at $32.7^{\circ} \mathrm{C}$ or $36.1^{\circ} \mathrm{C}$ for 2 weeks, $100 \%$ became sterile at the higher temperature, but only $43 \%$ under the less severe conditions. However, if the mice had been exposed to the hot conditions from weaning, $83 \%$ and $67 \%$, respectively were fertile at the lower and higher temperature when they reached adulthood 
(Pennycuik, 1967). In another study, transferring adult mice from $21^{\circ} \mathrm{C}$ to $35^{\circ} \mathrm{C}$ and $65 \%$ humidity for $24 \mathrm{~h}$ had no effect on their fertility, but exposure for $48 \mathrm{~h}$ reduced the percentage of pregnant females from $66 \%$ to $36 \%$, falling to $27 \%$ after $96 \mathrm{~h}$ and $18 \%$ after $120 \mathrm{~h}$ (Garriott and Chisman, 1981).

Burfening et al. (1970) exposed male mice to a chamber maintained at $32^{\circ} \mathrm{C}$ with $65 \%$ humidity for $24 \mathrm{~h}$, and then mated them with normal females. Embryos were recovered $48 \mathrm{~h}$ after a copulation plug had been found, and fertilization rate calculated from the ratio of cleaved ova to total ova recovered. They found that fertilization rate fell from $79 \%$ between days 1 and 5 after heating to 61,43 and $11 \%$ for days 6-10, 11-15 and 16-20, respectively, and then recovered to $55 \%$ and $79 \%$ for days $21-25$ and $26-30$ after heat treatment; control males had fertilization rates of between 78 and $91 \%$ over the same periods. In rats whose testes had been heated to $43^{\circ} \mathrm{C}$ for $30 \mathrm{~min}$, the fertilization rate of eggs collected the morning after mating was reduced from $76 \%$ to $17 \% 16$ to 20 days later, but there were fewer spermatozoa in the uterus of the non-pregnant females (Setchell et al., 1988). Dutt and Simpson (1957) noted that the fertilization rate in ewes increased by $38 \%$ when rams were kept in air-conditioned chambers during the summer months. Heating the testes of rams to $40.5^{\circ} \mathrm{C}$ for $2 \mathrm{~h}$ or $39.5^{\circ} \mathrm{C}$ for $4 \mathrm{~h}$ led to low fecundity between days 14 and 34 , and zero between days 34 and 47 (Braden and Mattner, 1970). Similarly, exposure of rams to an ambient temperature of $32^{\circ} \mathrm{C}$ and relative humidity of $65 \%$ for 4 days was followed by severely reduced fertility in week 2 and no pregnancies in week 3 (Howarth, 1969). When rams were exposed to $40.5^{\circ} \mathrm{C}$ for $8 \mathrm{~h}$, on one, two, three or four occasions on successive days, and then each mated between 10 and 27 days later to eight superovulated ewes, $93 \%$ of the eggs recovered $60-70 \mathrm{~h}$ after mating were fertilized by the control ram, whereas the percentage fell to $66,42,23$ and $6 \%$ respectively for the increasing times of heat exposure (Rathore, 1970). When boars were exposed to $34.5^{\circ} \mathrm{C}$ for $8 \mathrm{~h}$ and $31^{\circ} \mathrm{C}$ for $16 \mathrm{~h}$ per day for 6 weeks, and over the next 5 weeks were either allowed to mate with normal sows, or semen was collected and $6 \times 10^{9}$ spermatozoa per sow used for artificial insemination, $59 \%$ of the sows became pregnant by natural mating and $29 \%$ by artificial insemination, compared with 82 and $41 \%$, respectively for control boars (Wettemann et al., 1976, 1979). When ewes were inseminated in each uterine horn with $50 \times 10^{6}$ frozen-thawed spermatozoa from $16 \mathrm{~h}$ per day scrotal-insulated rams, the pregnancy rates at 17 days were not different from control values (Mieusset et al., 1992a).

However, with the exception of the experiments involving artificial insemination, most of these results could be explained by a reduced number of spermatozoa being available to fertilize the eggs, and even in the AI experiment, no allowance was made for the fact that the semen samples from the heated animals had lower motility than those of the controls. Nevertheless, when an equal number of motile swum-up spermatozoa from scrotal-insulated and control rams were used for in vitro fertilization, using ova obtained from ovaries collected at an abattoir, the percentage of eggs fertilized decreased from $73 \%$ to $7 \%$ with $16 \mathrm{~h}$ per day insulation for 18 days, and there were significant falls with
$8 \mathrm{~h}$ per day insulation for 5 weeks, both during the insulation period and during the following 2 weeks (Ekpe et al., 1992, 1993; see also Setchell 1994). AI was also undertaken with epididymal spermatozoa from mice whose testes had been heated to $42^{\circ} \mathrm{C}$ for $20 \mathrm{~min} 28$ days earlier. Fertilization rates were reduced ( $45 \%$ of oocytes fertilized compared with $65 \%$ for controls), but although the number and motility of spermatozoa were reduced (Jannes et al., 1998), the authors do not make it clear how many motile or total spermatozoa were used in the IVF.

\section{Embryonic development}

Probably the most surprising aspect of the effects of heat on the male is the possibility that there may be an effect on the development of embryos, even when the ova come from a normal female. In the experiments on guinea-pigs reported by Young (1927), he noted that there was an increase in the percentage of stillborn and aborted pups sired by the heated males when the proportion of sterile mating rose. For example, in the first 7 days after heating, only $7 \%$ of the matings were sterile and $7 \%$ of the pups were stillborn or aborted. In the second period, which extended from 8 days after heating to 48 days, $28 \%$ of the matings were sterile, and $25 \%$ of the pups were aborted or stillborn. Surprisingly, Young did not consider this rise in the proportion of abnormal pups to be necessarily a direct effect of the heating. Dutt and Simpson (1957) noted that embryonic death rate fell by $27 \%$ when rams were kept in air-conditioned chambers during the summer months. In the experiment by Burfening et al. (1970), for which the fertilization rates are given above, the authors also autopsied other females at day 10.5 of pregnancy and noted the number of corpora lutea, implantation sites and normal fetuses. From their data, it is possible to calculate the ratio of implantation sites to fertilized ova, and of fetuses to implantation sites. The latter remained between 86 and $96 \%$ for the heated males and 92 and $98 \%$ for the controls, but the ratio of implantation sites to fertilized ova was already less for the heated males in the first 5 days ( $71 \%$ versus $90 \%$ ), and continued to fall to $58 \%$ for days $6-10$ and to $55 \%$ for days $11-15$, while the values for control males stayed at $89 \%$ and $88 \%$ for the same periods. This sugggests that even epididymal spermatozoa may be affected as well as cells developing in the testis in such a way as to affect the developmental capacity of the embryos they produce, as the matings achieved on days 1-5 would involve spermatozoa already in the epididymis. This was also the case in the experiments reported by Mieusset et al. (1992a); ewes inseminated with frozen-thawed semen collected from rams 4 days after the beginning of scrotal insulation showed a greater loss of embryos between day 17 and day 65 of pregnancy, although the loss became more pronounced when the semen was collected 11 or 18 days after the start of insulation.

Bellve $(1972,1973)$ found that following exposure of male mice to an ambient temperature of $34.5^{\circ} \mathrm{C}$ and $65 \%$ humidity for $24 \mathrm{~h}$, that there was an extensive embryonic mortality evident by day 10.5 of gestation and developmental retardation, as evidenced by an accumulation of four-cell 
embryos at $54 \mathrm{~h}$ after coitus when the males were mated to normal females 6 days later. The eight-cell embryos sired by heated males were less able to incorporate $\left[{ }^{3} \mathrm{H}\right]$ uridine. Bellve also found reduced numbers of blastocysts in vivo $120 \mathrm{~h}$ after hCG injection and two-cell embryos recovered from normal females and cultured in vitro showed a minor arrest at the eight-cell stage, and a substantial accumulation of morulae, so that the number of blastocyts was reduced. When normal female rats were mated to males whose testes had been heated to $43^{\circ} \mathrm{C}$ for $30 \mathrm{~min}$, before the males became sterile, and during recovery of fertility, there were periods when litter size and the fetus to corpus luteum ratios were reduced, suggesting that there was significant mortality of the embryos. There was also an increased incidence of degenerating embryos at 2 and 15 days of pregnancy (Setchell et al., 1988). However, with male rats acclimatized for 3 months to $35^{\circ} \mathrm{C}$, although the mating rate was only $17 \%$ and conception rate $40 \%$, compared with $52 \%$ and $71 \%$, respectively for controls, the development of the embryos once conceived appeared to be normal (Sod-Moriah et al., 1974).

In the experiments with pigs by Wettemann et al. (1976, 1979) for which the fertilization data are given above, an estimate was also made of the survival of the embryos to 30 days after coitus. In the artificially inseminated sows, embryo survival was only $49 \%$ with semen from the heated males, compared with $71 \%$ with semen from control males. An equivalent difference was not seen in sows mated naturally ( $79 \%$ versus $82 \%$ ), and the authors suggest that this is because of the larger numbers of spermatozoa inseminated during a natural mating.

There is also some evidence that even the heating of ejaculated spermatozoa can cause increased embryo mortality if they are subsequently used for insemination (Young, 1929; Howarth et al., 1965; Ulberg and Burfening, 1967).

The sheep embryos produced by in vitro fertilization, using semen from scrotal-insulated rams developed slightly less well than those obtained with control semen, and there was increased degeneration at the blastocyst stage (Ekpe et al., 1992, 1993; see also Setchell 1994).

When the testes of male mice were heated to $42^{\circ} \mathrm{C}$ for 20 min, although the animals remained fertile (see above) and litter size was not reduced, the embryos they sired were about $25 \%$ smaller than controls at 10.5 days of gestation in three separate experiments with different strains of mice; at later stages of pregnancy, the difference became smaller, but in one experiment, although not in a second, the differences were still significant at 15.5 and 18.5 days. The difference did not appear to be due to later mating by the heated males, and the timing of the growth retardation differed from that seen in mice lacking IGF-II, of which only the paternal copy is expressed in the embryo (see Setchell et al., 1998). These findings of smaller fetuses with normal litter size from heatexposed sires have been confirmed by Jannes et al. (1998), for embryos at 14.5 days. This finding was not entirely unexpected, in view of the findings that human semen of poor quality, not necessarily caused by heat, appears to produce poor quality embryos (Ron-El et al., 1991; Parinaud et al., 1993; Janny and Menezo, 1994).

\section{Mechanism of effects of heat}

Because of the wide range of effects of heat on the testis, as described above, it is difficult to propose a single cause. Either a variety of cell types are affected in different ways, or one cell type is primarily affected, and there are secondary effects on the other cells. As the Leydig cells do not appear to be directly affected by heating, or if they are, are only minimally affected, the most obvious cell to be the primary site of action of heat is the Sertoli cell. Because of its position in the seminiferous epithelium, it is able to have a profound influence on all germ cells once they pass through the blood-testis barrier. These germ cells probably depend almost entirely on the Sertoli cells for nutrients and their development is controlled by influences from the Sertoli cells. The Sertoli cells probably even have an influence on cells such as the spermatogonia and preleptotene spermatocytes that are in the basal compartment, on the blood side of the specialized junctions between the Sertoli cells, which form the major site for the barrier inside the tubules.

However, there is very little direct evidence that the Sertoli cells are affected by heat. Secretion of fluid does appear to be reduced under some circumstances, but not in the first $24 \mathrm{~h}$ after the testis has been made cryptorchid. However, there may be more subtle changes in composition of the secreted fluid not reflected in total volume secreted and it would seem logical to examine the composition of the secretion by these cells at different temperatures, as the secretion contains high concentrations of many substances that are either not found elsewhere in the body, or are present at much lower concentrations. An effect on the Sertoli cells could influence chromosome behaviour during the meiotic prophase, and investigations on the effects of heat on the synaptonemal complex may be warranted.

The only effects that cannot be explained by a primary effect on the Sertoli cells are those involving the spermatozoa in the epididymis. Although these are not major, there does appear to be evidence for them, although most authors agree that epididymal spermatozoa are much less susceptible. However, it has been suggested that the epididymis is the prime mover in the evolution of the scrotum (Bedford, 1978), and these effects of heat on epididymal spermatozoa merit further investigation. In addition, as when the spermatozoa leave the testis they are incapable of fertilizing ova, unless injected directly into the egg cytoplasm, an epididymal effect could contribute to the reduction in capacity of the spermatozoa, although motile, to fertilize.

The fact that blood flow through the testis does not increase at all, or not sufficiently to match the increase in metabolism, means that the heated testis is probably hypoxic. Damage may be caused not so much by the hypoxia directly, as by the generation of reactive oxygen species during the recovery phase, as occurs after ischaemia in many other tissues and the effect of scavengers for ROS during heating or immediately afterwards is probably worth investigating.

The many changes in enzymes and in heat shock factors and heat shock proteins must be evaluated to determine whether these responses are deleterious or are an attempt by 
the testis to protect itself against the effects of heat. The latter is probably the case with the haeme oxygenase enzymes.

As there is now evidence that the contribution of the paternal and maternal gamete to the embryo is not the same, so-called 'genomic imprinting' (see Ohlsson et al., 1995), it seemed possible that heat may have been interfering with the process whereby the paternal genome is identified as such. This does not appear to be the case for the imprinted gene most obviously concerned with fetal growth, IGF-II, but there are now many such genes, and it is possible that the imprinting signal is not being properly added to the spermatozoa. There is also evidence for non-genomic contributions by the spermatozoa to the embryo (Browning and Strome, 1996), and it is possible that the factor or factors may be influenced by temperature.

\section{Conclusions}

Although it is not yet possible to explain why spermatogenesis is so sensitive to heat, the fact remains that heat or summer sterility is recognized as a major problem in farm animals (see Setchell, 1978). More recently, there has been evidence provided that in humans, increased testis temperatures, either due to occupational hazards or clothing fashions may be contributing significantly to infertility or subfertility problems (Mieusset and Bujan, 1995; Parazzini et al., 1995; Thonneau et al., 1997). Heating has also been considered as a possible contraceptive technique (see Kandeel and Swerdloff, 1988). It has even been suggested that global warming may be a possible cause of the decline in human sperm counts reported by some authors. If this is the case, it is surprising that similar falls have not been detected in any of the farm animals, for which much more data have been collected, and which would have been much more directly influenced by climatic change (see Setchell, 1997; van Os et al., 1997).

I am grateful to EM Ritzen, O Söder and L Plöen in Stockholm, AF Holstein, R Ivell, MS Davidoff, C Kirchhoff anf R Middendorff in Hamburg and RS Swerdloff for useful discussion during the preparation of this review, and to the Nobel Foundation for financial support.

\section{References}

Ahotupa M and Huhtaniemi I (1992) Impaired detoxification of reactive oxygen and consequent oxidative stress in experimentally cryptorchid rat testis Biology of Reproduction 46 1114-1118

Allan DJ, Harmon BV and Kerr JFR (1987) Cell death in spermatogenesis. In Perspectives on Mammatian Cell Death pp 229-258 Ed. CS Potten. Oxford University Press, London

Allen RL, O'Brien DA, Jones CC, Rockett DL and Eddy EM (1988a) Expression of heat shock proteins by isolated mouse spermatogenic cells Molecular and Cellular Biology 8 3260-3266

Allen RL, O'Brien DA and Eddy EM (1988b) A novel hsp70-like protein (P70) is present in mouse spermatogenic cells Molecular and Cellular Biology 8 828-832

Almon E, Goldfinger N, Kapon A, Schwartz D, Levine AJ and Rotter V (1993) Testicular tissue-specific expression of the p53 suppressor gene Developmental Biology 156 107-116

Amatyakul K, Ryan R, Uozumi T and Albert A (1971) Reinvestigation of testicular-anterior pituitary relationships in the rat. 1. Effects of castration and cryptorchidism Endocrinology 88 872-880
Antich M, Fabian E, Sarquella J and Bassas L (1995) Effect of testicular damage induced by cryptorchidism on insulin-like growth factor I receptors in rat Sertoli cells Journal of Reproduction and Fertility 104 267-275

Austin JW, Hupp EW and Murphree RL (1961) Effect of scrotal insulation on semen of Hereford bulls Journal of Animal Science 20 307-310

Barenton B, Blanc MR, Caraty A, Hochereau-de Reviers MT and Perreau C (1982) Effect of cryptorchidism in the ram: changes in the concentration of testosterone and estradiol and receptors for LH and FSH in the testis and its histology Molecular and Cellular Endocrinology 28 13-25

Bartlett JMS and Sharpe RM (1987) Effect of local heating of the rat testis on the levels in interstitial fluid of a putative paracrine regulator of the Leydig cells and its relationship to changes in Sertoli cell secretory function Journal of Reproduction and Fertility 80 279-287

Beaupré CE, Tressler CJ, Beaupre SJ, Morgan JLM, Bottje WG and Kirby JD (1997) Determination of testis temperature rhythms and effects of constant light on testicular function in the domestic fowl (Gallus domesticus). Biology of Reproduction 56 1570-1575

Bedford JM (1978) Anatomical evidence for the epididymis as the prime mover in the evolution of the scrotum American Journal of Anatomy 152 483-508

Bedrak E, Chap Z and Fried K (1980) Factors for consideration in the interpretation of the adverse effects of elevated environmental temperatures on reproduction in the male rat International Journal of Biometeorology 24 117-128

Bellvé AR (1972) Viability and survival of mouse embryos following parental exposure to high temperature Journal of Reproduction and Fertility 30 71-81

Bellvé AR (1973) Development of mouse embryos with abnormalities induced by parental heat stress Journal of Reproduction and Fertility 35 393-403

Bergh A and Damber JE (1978) Testicular development in the unilaterally cryptorchid rat International Journal of Andrology 1 352-356

Bergh A and Damber JE (1984) Local regulation of Leydig cells by the seminiferous tubules. Effect of short-term cryptorchidism International Journal of Andrology 7 409-418

Bergh A, Helander HF and Wahlqvist L (1978) Studies on factors governing testicular descent in the rat-particularly the role of the gubernaculum testis International Journal of Andrology 1 440-458

Bergh A, Åson Berg A, Damber JE, Hammar M and Selstam G (1984) Steroid biosynthesis and Leydig cell morphology in adult unilaterally cryptorchid rats Acta Endocrinologica 107 556-562

Bergh A, Damber JE, Jacobsson H and Nilsson TK (1987) Production of lactate and tissue plasminogen activator in vitro by seminiferous tubules obtained from adult unilaterally cryptorchid rats Archives of Andrology 19 177-182

Biggiogera M, Tanguay RM, Marin R, Wu Y, Martin TE and Fakan S (1996) Localization of heat shock proteins in mouse male germ cells: an immunoelectron microscopical study Experimental Cell Research 229 77-85

Blackshaw AW and Hamilton D (1970) The effect of heat on hydrolytic enzymes and spermatogenesis in the rat testis Journal of Reproduction and Fertility 22 569-571

Blackshaw AW and Massey PF (1978) The effect of cryptorchidism on the quantitative histology, histochemistry and hydrolytic enzyme activity of the rat testis Australian Journal of Biological Sciences 31 53-64

Blix AS, Fay FH and Ronald K (1983) On testicular cooling in phocid seals Polar Research 1231-233

Bowler K (1972) The effect of repeated applications of heat on spermatogenesis in the rat: a histological study Journal of Reproduction and Fertility 28 325-333

Boylan ES (1978) Morphological and functional consequences of prenatal exposure to diethylstilbestrol in the rat Biology of Reproduction 19 854-863

Braden AWH and Mattner PE (1970) The effects of scrotal heating in the ram on semen characteristics, fecundity and embryonic mortality Australian journal of Agricultural Research 21 509-518

Bronson FH and Heideman PD (1993) Failure of cryptorchidism to suppress fertility in a tropical rodent Biology of Reproduction 48 1354-1359

Browning $\mathbf{H}$ and Strome S (1996) A sperm-supplied factor required for embryogenesis in C. elegans. Development $122391-404$

Brown-Woodman PDC, Post EJ, Gass GC and White IG (1984) The effect of a single sauna exposure on spermatozoa Archives of Andrology 129-15

Bryden MM (1967) Testicular temperature in the southern elephant seal, Mirounga leonina (Linn.) Journal of Reproduction and Fertility 13 583-584

Burfening PJ, Elliott DS, Eisen EJ and Ulberg LC (1970) Survival of embryos resulting from spermatozoa produced by mice exposed to elevated ambient temperature Journal of Animal Science 30 578-582 
Byers SW and Glover TD (1984) Effect of scrotal insulation on the pituitary-testicular axis of the ram Journal of Reproduction and Fertility 71 21-31

Casady RB, Myers RM and Legates JE (1953) The effect of exposure to high ambient temperature on spermatogenesis in the dairy bull journal of Dairy Science 36 14-23

Cataldo L, Mastrangelo MA and Kleene KC (1997) Differential effects of heat shock on translation of normal mRNAs in primary spermatocytes, elongated spermatids and Sertoli cells in seminiferous tubule culture Experimental Cell Research 231 206-213

Chance MRA (1996) Reason for externalization of the testis of mammals Journal of Zoology 239 691-695

Chowdhury AK and Steinberger E (1964) A quantitative study of the effect of heat on the germinal epithelium of the rat testis American Journal of Anatomy $115509-524$

Chowdhury AK and Steinberger E (1970) Early changes in the germinal epithelium of rat testes following exposure to heat Journal of Reproduction and Fertility 22 205-212

Clark AM and Griswold MD (1997) Expression of clusterin/sulfated glycoprotein-2 under conditions of heat stress in rat Sertoli cells and a mouse Sertoli cell line Journal of Andrology 18 257-263

Clegg EJ (1960) Some effects of artificial cryptorchidism on the accessory reproductive organs of the rat Journal of Endocrinology 20 210-219

Clegg EJ (1963) Studies on artificial cryptorchidism: degenerative and regenerative changes in the germinal epithelium of the rat testis Journal of Endocrinology $27241-251$

Collins P and Lacy D (1969) Studies on the structure and function of the mammalian testis. II. Cytological and histochemical observations on the testis of the rat after a single exposure to heat applied for different lengths of time Proceedings of the Royal Society of London B 172 17-38

Cowles RB (1965) Hyperthermia, aspermia, mutation rates and evolution Quarterly Review of Biology 40 341-367

Crew FAE (1922) A suggestion as to the cause of the aspermatic condition of the imperfectly descended testis Journal of Anatomy 56 98-106

Cunningham B and Osborn G (1929) Infra-red sterility: preliminary report Endocrinology 1393-96

Damber JE and Janson PO (1978) The influence of scrotal warming on testicular blood flow and endocrine function in the rat Acta Physiologica Scandinavica 104 61-67

Damber JE, Bergh A and Janson PO (1980) Leydig cell function and morphology in the rat testis after exposure to heat Andrologia 12 12-19

Davis JR and Firlit CF (1966) The germinal epithelium of cryptorchid testes experimentally induced in prepubertal and adult rats Fertility and Sterility $17187-200$

De Vita R, Calugi A, Chiarantano C, Forte D, Mauro F and Uccelli R (1990) Effects on mouse spermatogenesis monitored by flow cytometry International Journal of Hyperthermia 6 543-551

Dix DJ (1997) Hsp70 expression and function during gametogenesis Cell Stress and Chaperones 273-77

Dumontier A, Burdick A, Ewigman B and Fahim MS (1977) Effects of sonication on mature rat testes Fertility and Sterility 28 195-204

Dutt RH and Hamm PT (1957) Effect of exposure to high environmental temperature and shearing on semen production of rams in winter journal of Animal Science 16 328-334

Dutt RH and Simpson EC (1957) Environmental temperature and fertility of Southdown rams early in the breeding season Journal of Animal Science 16 136-143

Dutt RH, Sand RS and Singh B (1977) Changes in testis blood flow, the spermatic artery and prostaglandin $F_{2 \alpha}$ content in testis tissue of heatstressed rams Internatinal journal of Biometeorology 21 75-84

Ehrenberg L, Ehrenstein G von and Hedgram A (1957) Gonad temperature and spontaneous mutation rate in man Nature 180 1433-1444

Ekpe G, Seamark RF, Sowerbutts SF and Setchell BP (1992) Effect of intermittent scrotal insulation on fertilizing ability of ram spermatozoa and the development of the embryos to blastocysts in vitro. Proceedings of the Australian Society for Reproductive Biology 2451

Ekpe G, Zupp JL, Seamark SF and Setchell BP (1993) Fertilising ability of spermatozoa from rams subjected to intermittent scrotal insulation and development of the resultant embryos in vitro. Proceedings of the Australian Society for Reproductive Biology 2588

Elfving G (1950) Effects of the Local Application of Heat on the Physiology of Testis. An Experimental Study in Rats Doctoral Thesis, Helsinki

Ellegren H and Fridolfsson A-K (1997) Male-driven evolution of DNA sequences in birds. Nature Genetics 17 182-184 [see also Crow JF (1997) Molecular evolution - who is in the driver's seat Nature Genetics 17 129-130, Lesselle K (1997) More mutations in males Nature 390 236-237, Dickman S (1997) Males mutate more, bird study shows Science 276 34]

Ewing JF and Maines MD (1995) Distribution of constitutive (HO-2) and heatinducible (HO-1) heme oxygenase isoenzymes in rat testes: HO-2 displays stage-specific expression in germ cells Endocrinology 136 2294-2302

Fahim MS, Fahim Z, Der R, Hall DG and Harman J (1975) Heat in male contraception (hot water $60^{\circ} \mathrm{C}$, infrared, microwave and ultrasound) Contraception 11 549-562

Farooqui SM, Al-Bagdadi FA, O'Donnell JM and Stout R (1997) Degenerative changes in spermatogonia are associated with loss of glucose transporter (Glut 3) in abdominal testis of surgically induced unilateral cryptorchidism in rats Biochemical and Biophysical Research Communications $236407-412$

Fowler DG (1968) Skin folds and Merino breeding 7. The relations of heat applied to the testis and scrotal thermoregulation to fertility in the Merino ram Australian Journal of Experimental Agriculture and Animal Husbandry 8 $142-148$

Frankenhuis MT and Wensing CJG (1979) Induction of spermatogenesis in the naturally cryptorchid pig Fertility and Sterility 31 428-433

Free MJ and VanDemark NL (1968) Gas tensions in spermatic and peripheral blood of rams with normal and heat-treated testes American Journal of Physiology 214 863-865

Freeman S (1990) The evolution of the scrotum: a new hypothesis Journal of Theoretical Biology 145 429-445

Freidman R, Scott M, Heath SE, Hughes JP, Daels PF and Tran TQ (1991) The effects of increased testicular temperature on spermatogenesis in the stallion Journal of Reproduction and Fertility 44 127-134

French DJ, Leeb CS, Fahrion SL, Law OT and Jecht EW (1973) Self-induced scrotal hyperthermia in man followed by decrease in sperm output. A preliminary report Andrologie 4 311-316

Fridd CW, Murphy J, Linke CA and Bonfoglio TA (1975) Response of rat testis to localized induced hyperthemia Urology 5 76-82

Fujisawa M, Matsumoto O, Kamidono S, Hirose F, Kojima K and Yoshida S (1988) Changes of enzymes involved in DNA synthesis in the testes of cryptorchid rats Journal of Reproduction and Fertility 84 123-130

Fujisawa M, Hayashi A, Okada H, Arakawa S and Kamidono S (1997) Enzymes involved in DNA synthesis in the testes are regulated by temperature in vitro. European Urology 31 237-242

Fukui $\mathbf{N}$ (1923a) On a hitherto unknown action of heat on rat testicles Japanese Medical World $327-28$

Fukui N (1923b) Action of body temperature on the testicle Japanese Medical World 3 160-163

Fukui N (1923-4) On the action of heat rays upon the testicle: an histological, hygenic and endocrinological study Acta Scholensis Medica Kyoto 6 225-258

Galil KAA and Setchell BP (1988a) Effects of local heating of the testes on the concentration of testosterone in jugular and testicular venous blood of rats and on testosterone production in vitro. International Journal of Andrology 11 $61-72$

Galil KAA and Setchell BP (1988b) Effects of local heating of the testis on testicular blood flow and testosterone secretion in the rat International Journal of Andrology 11 73-85

Garriott ML and Chisman CL (1980) Hyperthermia induced dissociation of the $X-Y$ bivalent in mice Environmental Mutagenesis $2465-471$

Garriott ML and Chisman CL (1981) Investigation of hyperthermia-induced dominant lethal mutations in male mice Journal of Heredity 72 338-342

Gasinska A and Hill S (1990) The effect of hyperthermia on the mouse testis Neoplasma 37 357-366

Glover TD (1955) Some effects of scrotal insulation on the semen of rams Proceedings of the Society for the Study of Fertility 7 66-75

Glover TD (1956) The effect of scrotal insulation and the influence of the breeding seasons upon fructose concentration in the semen of the ram Journal of Endocrinology 13 235-242

Godinho HP and Setchell BP (1975) Total and capillary blood flow through the testes of anaesthetized rams Journal of Physiology 251 19P-20P

Gomes WR, Butler WR and Johnson AD (1971) Effects of elevated ambient temperature on testis and blood levels and in vitro biosynthesis of testosterone in the ram Journal of Animal Science 33 804-807

Griffiths J (1893) Structural changes in the testicle of the dog when it is replaced within the abdominal cavity Journal of Anatomy and Physiology 27 483-500

Gupta D, Rager K, Zarzycki J and Eichner M (1975) Levels of luteinizing 
hormone, follicle-stimulating hormone, testosterone and dihydrotestosterone in the circulation of sexually maturing intact male rats and after orchidectomy and experimental bilateral cryptorchidism Journal of Endocrinology 66 183-193

Hagenäs L, Plöen L, Ritzen EM and Ekwall H (1977) Blood-testis barrier: maintained function of inter-Sertoli cell junctions in experimental cryptorchidism in the rat, as judged by a simple lanthanum-immersion technique Andrologia 9 250-254

Hand JW, Walker H, Hornsey S and Field SB (1979) Effects of hyperthermia on the mouse testis and its response to $\mathrm{X}$-rays, as assayed by weight loss International Journal of Radiation Biology 35 521-528

Haugen TB, Hansson V and Fritzson P (1988) Cellular distribution, developmetnal changes and effects of cryptorchidism on uridine kinase in the rat testis fournal of Reproduction and Fertility 85 655-661

Henriksen K, Hakovirta H and Parvinen M (1995) In situ quantification of stage-specific apoptosis in the rat seminiferous epithelium: effects of shortterm experimental cryptorchidism International Journal of Andrology 18 256-262

Hochereau-de Reviers MT, Blanc MR, Cahoreau C, Courot M, Dacheux JL and Pisselet C (1979) Histological testicular parameters in bilateral cryptorchid adult rams Annales de Biologie Animale, Biochemie et Biophysique $191141-1146$

Hochereau-de Reviers MT, Locatelli A, Perreau C, Pisselet C and Setchell BP (1993) Effects of a single brief period of moderate heating of the testis on seminiferous tubules in hypophysectomized rams treated with pituitary extract Journal of Reproduction and Fertility 97 381-387

Hoffmann AM, Bergh A and Olivecrona T (1989) Changes of testicular cholesteryl ester hydrolase activity in experimentally cryptorchid rats Journal of Reproduction and Fertility 86 11-18

Holash JA, Harik SI, Perry G and Stewart PA (1993) Barrier properties of testis microvessels Proceeding of the National Academy of Sciences USA 90 11069-11073

Hotta Y, Fujisawa M, Tabata S, Stern H and Yoshida S (1988) The effect of temperature on recombination activity in testes of rodents Experimental Cell Research 178 163-168

Howarth B (1969) Fertility in the ram following exposure to elevated ambient temperature and humidity Journal of Reproduction and Fertility 19 179-183

Howarth B, Alliston CW and Ulberg LC (1965) Importance of uterine environment on rabbit sperm prior to fertilization Journal of Animal Science 24 1027-1032

Husmann DA and McPhaul MJ (1991) Time-specific androgen blockade with flutamide inhibits testicular descent in the rat Endocrinology 129 1409-1416

Hutson JM, Watts IM, Montalto J and Greco S (1990) Both gonadotropin and testosterone fail to resolve estrogen-induced cryptorchidism in fetal mice: further evidence for nonandrogenic control of testicular descent in the fetus Pediatric Surgery 5 13-18

Hutson JM, Hasthorpe S and Heyns CF (1997) Anatomical and functional aspects of testicular descent and cryptorchidism Endocrine Reviews 18 259-280

Idänpään-Heikkilä P (1966) Effect of local heat in vivo on the fine structure of the basement membrane and the Sertoli cells of the rat testis Fertility and Sterility 17 689-695

Imig CJ, Thomson JD and Hines HM (1948) Testicular degeneration as a result of microwave irradiation Proceeding of the Society for Experimental Biology and Medicine 69 382-386

Jahnsen T, Attramadal H, Karpe B, Ritzén M and Hansson V (1986) Changes in germ cell adenylate cyclase and protein carboxyl methylase activities in rat testicular tissue during bilateral cryptorchidism and after orchidopexy Journal of Reproduction and Fertility 77 317-320

Jannes P, Spiessens C, Van der Auwera I, D'Hooghe T, Verhoeven G and Vanderschueren D (1998) Male subfertility induced by acute scrotal heating affects embryo quality in normal female mice Human Reproduction 13 372-375

Janny L and Menezo YJR (1994) Evidence for a strong paternal effect on human preimplantation embryo development and blastocyst formation Molecular Reproduction and Development 38 36-42

Jansz GF and Pomerantz DK (1986) A comparison of Leydig cell function after unilateral and bilateral cryptorchidism and efferent-duct-ligation Biology of Reproduction 34 316-321

Jegou B, Laws AO and de Kretser DM (1984) Changes in testicular function induced by short-term exposure of the rat testis to heat: further evidence for interaction of germ cells, Sertoli cells and Leydig cells International Journal of Andrology 7 244-257

Kandeel FR and Swerdloff RS (1988) Role of temperature in regulation of spermatogenesis and the use of heating as a method for contraception Fertility and Sterility 49 1-23

Karabinus DS, Vogler CJ, Saacke RG and Evenson DP (1997) Chromatin structural changes in sperm after scrotal insulation of Holstein bulls Journal of Andrology 18 549-555

Karpe B, Plöen L, Hagenäs L and Ritzén EM (1981) Recovery of testicular functions after surgical treatment of experimental cryptorchidism in the rat International journal of Andrology 4 145-160

Karpe B, Plöen L and Ritzén EM (1984) Maturation of the juvenile rat testis after surgical treatment of cryptorchidism International Journal of Andrology 7 154-161

Kastelic JP, Cook RB, Coulter GH and Saacke RG (1996) Insulating the scrotal neck affects semen quality and scrotal/testicular temperatures in the bull Theriogenology 45 935-942

Keel BA and Abney TO (1980) Influence of bilateral cryptorchidism in the mature rat: alterations in testicular function and serum hormone levels Endocrinology 107 1226-1233

Krawczyk Z, Szymik N and Wisniewski J (1987) Expression of hsp-related gene in developing and degenerating rat testis Molecular Biology Reports 12 35-41

Krawczyk Z, Wisniewski J and Biesiada E (1988) A rat testis-specific hsp70 gene-related transcript is coded by a novel gene from the hsp70 multigene family Acta Biochimica Polonica 35 378-385

Larsson K and Einarsson S (1984) Seminal changes in boars after heat stress Acta Veterinaria Scandinavica $2557-66$

Larsson K, Einarsson S, Lundström K and Hakkarainen J (1983) Endocrine effects of heat stress in boars Acta Veterinaria Scandinavica 24 305-314

Lee LPK (1974) Temperature effect on the permeability of plasma membranes of advanced germinal cells of the rat testis Canadian Journal of Biochemistry 52 $586-593$

Lee LPK and Fritz IB (1972) Studies on spermatogenesis in rats. V. Increased thermolability of Iysosomes from testicular germ cells and its possible relationship to impairments in spermatogenesis in cryptorchidism Journal of Biological Chemistry 247 7956-7961

Lemaire $\mathbf{L}$ and Heinlein UAO (1991) Detection of secreted and temporarily inducible heat shock responsive proteins in mouse testicular tissue Life Sciences 48 365-372

Linzell JL and Setchell BP (1969) Metabolism, sperm and fluid production of the isolated perfused testis of the sheep and goat Journal of Physiology 201 129-143

Lue YH, Sinha Hikim AP, Leung A, Baravarian S, Wang C and Swerdloff RS (1998) Stage-specific hormonal protection against heat-induced germ cell apoptosis in rat Journal of Andrology 19 Supplement 29

Lunstra DD and Schanbacher BD (1988) Testicular function and Leydig cell ultrastructure in long-term bilaterally cryptorchid rams Biology of Reproduction 38 211-220

McLaren TT, Foster PMD and Sharpe RM (1994) Identification of stagespecific changes in protein secretion by isolated seminiferous tubules from rats following exposure to short-term local testicular heating Journal of Reproduction and Fertility $102293-300$

MacLeod J and Hotchkiss RS (1941) The effect of hyperpyrexia upon spermatozoa counts in men Endocrinology 28 780-784

McNitt JL and First NL (1970) Effects of 72-hour heat stress on semen quality in boars International Journal of Biometeorology 14 373-380

McVean GT and Hurst LD (1997) Evidence for a selectively favourable reduction in the mutation rate of the $X$ chromosome Nature 386 388-392

Magal E, Kaplamski J, Sod-Moriah U, Hirschmann N and Nir I (1981) Role of the pineal gland in male rats chronically exposed to increased temperature Journal of Neural Transmission $\mathbf{5 0} 267-273$

Main SJ and Waites GMH (1977) The blood-testis barrier and temperature damage to the testis of the rat Journal of Reproduction and Fertility $51439-450$

Main SJ, Davies RV and Setchell BP (1978) Feedback control by the testis of gonadotrophin secretion: an examination of the inhibin hypothesis Journal of Endocrinology 79 255-270

Maines MD and Ewing JF (1996) Stress response of the rat testis: in situ hybridization and immunohistochemical analysis of heme oxygenase-1 (HSP32) induction by hyperthermia Biology of Reproduction 54 1070-1079

Malmgren L (1989) Experimentally induced testicular alterations in boars: sperm morphology changes in mature and peripubertal boars journal of Veterinary Medicine A $36411-420$

Malmgren L (1990) Experimentally induced testicular alterations in boars: hormonal changes in mature and peripubertal boars Acta Veterinaria Scandinavica 31 97-107

Malmgren L and Larsson K (1984) Semen quality and fertility after heat stress in boars Acta Veterinaria Scandinavica 25 425-435 
Malmgren L and Larsson K (1989) Experimentally induced testicular alterations in boars: histological and ultrastructural findings Journal of Veterinary Medicine A 36 3-14

Marigold JCL, Hume SP and Hand JW (1985) Investigation of thermotolerance in mouse testis International Journal of Radiation Biology 48 589-595

Mauss J (1971) A model for testing the effect of drugs on the regeneration of spermatogenesis in the rat Experientia 271501

Meistrich ML, Eng VWS and Loir M (1973) Temperature effects on the kinetics of spermatogenesis in the mouse Cell and Tissue Kinetics 6 379-393

Mieusset R and Bujan L (1995) Testicular heating and its possible contributions to male infertility: a review International Journal of Andrology $18169-184$

Mieusset R, Grandjean H, Mansat A and Pontonnier F (1985) Inhibiting effect of artificial cryptorchidism on spermatogenesis Fertility and Sterility 43 589-593

Mieusset R, Bujan L, Mansat A, Pontonnier F and Grandjean H (1987a) Hyperthermia and human spermatogenesis: enhancement of the inhibitory effect obtained by 'artificial cryptorchidism' International Journal of Andrology 10 571-580

Mieusset R, Bujan L, Mansat A, Pontonnier F and Grandjean H (1987b) Effect of artificial cryptorchidism on sperm morphology Fertility and Sterility 47 150-155

Mieusset R, Quintana Casares PI, Sanchez-Partida LG, Sowerbutts SF, Zupp JL and Setchell BP (1991) The effects of moderate heating of the testes and epididymides of rams by scrotal insulation on body temperature, respiratory rate, spermatozoa output and motility, and on fertility and embryonic survival in ewes inseminated with frozen semen Annals of the New York Academy of Sciences 637 445-458

Mieusset R, Quintana Casares P, Sanchez Partida LG, Sowerbutts SF, Zupp JL and Setchell BP (1992a) The effects of heating the testes and epididymides of rams by scrotal insulation on fertility and embryonic mortality in ewes inseminated with frozen semen journal of Reproduction and Fertility $94337-343$

Mieusset R, Sowerbutts SF, Zupp JL and Setchell BP (1992b) Increased testicular blood plasma flow during local heating of the testes of rams Journal of Reproduction and Fertility 94 345-352

Minton JE, Wettemann RP, Meyerhoeffer DC, Hintz RL and Turman EJ (1981) Serum luteinizing hormone and testosterone in bulls during exposure to elevated ambient temperature Journal of Animal Science $\mathbf{5 3}$ $1551-1558$

Moore CR (1924a) Properties of the gonads as controllers of somatic and psychical characteristics. VI. Testicular reactions to experimental cryptorchidism American Journal of Anatomy 34 269-316

Moore CR (1924b) Properties of the gonads as controllers of somatic and psychical characteristics. VIII. Heat application and testicular degeneration: the function of the scrotum American Journal of Anatomy 34 337-358

Moore CR and Oslund R (1924) Experiments on the sheep testis cryptorchidism, vasectomy, scrotal insulation American Journal of Physiology 67595-607

Moule GR and Waites GMH (1963) Seminal degeneration in the ram and its relation to the temperature of the scrotum Journal of Reproduction and Fertility $5433-446$

Nakamura M and Hall PF (1980) The mechanism by which body temperature inhibits protein biosynthesis in spermatids of rat testes Journal of Biological Chemistry 255 2907-2913

Nakamura M, Romrell LJ and Hall PF (1978) The effects of temperature and glucose on protein biosynthesis by immature (round) spermatids from rat testis Journal of Cell Biology 79 1-9

Nakamura $M$, Namiki M, Okuyama A, Matsui T, Doi $X$, Takeyama $M$, Fujioka H, Nishimune Y, Matsumoto $K$ and Sonoda T (1987) Temperature sensitivity of human spermatogonia and spermatocytes in vitro. Archives of Andrology 19 127-132

Nakamura M, Namiki M, Okuyama A, Koh E, Kondoh N, Takeyama M, Fujioka H, Nishimune $Y$, Matsumoto $K$ and Matsuda $M$ (1988) Optimal temperature for synthesis of DNA, RNA and protein by human testis in vitro. Archives of Andrology 20 41-44

Nelson WO (1951) Mammalian spermatogenesis: effects of experimental cryptorchidism in the rat and non-descent of the testis in man Recent Progress in Hormone Research $629-56$

Niemi M and Kormano M (1965) Response of the cycle of the seminiferous epithelium of the rat testis to artificial cryptorchidism Fertility and Sterility $16236-242$
Nishimune $Y$ and Komatsu $T$ (1972) Temperature sensitivity of mouse testicular DNA synthesis in vitro. Experimental Cell Research 75 514-517

Nishiyama H, Danno S, Kaneko X, Itoh K, Yokoi H, Fukumoto M, Okuno H, Millan JL, Matsuda T, Yoshida O and Fujita J (1998) Decreased expression of cold-inducible RNA-binding protein (CIRP) in male germ cells at elevated temperature American Journal of Pathology 152 289-296

Ohlsson R, Hall K and Ritzén EM (Eds) (1995) Genomic Imprinting Causes and Consequences Cambridge University Press, Cambridge

Pabst DA, Rommel SA, McLellan WA, Williams TM and Rowles TK (1995) Thermoregulation of the intra-abdominal testes of the bottlenose dolphin (Tursiops truncatus) during exercise Journal of Experimental Biology 198 221-226

Parazzini F, Marchini M, Luchini L, Tozzi L, Mezzopane R and Fedele L (1995) Tight underpants and trousers and the risk of dyspermia International Journal of Andrology 18 137-140

Parinaud J, Labal B, Mieusset R, Richoilley G and Vieitez G (1993) Influence of sperm parameters on embryo quality Fertility and Sterility 60 888-892

Parvinen M (1973) Observations of freshly isolated and accurately identified spermatogenic cells of the rat. Early effects of heat and short-term experimental cryptorchidism Virchows Archiv Abteilung B Zellpathologie 13 38-47

Parvinen M, Pelto-Huikko M, Söder O, Schultz R, Kaipia A, Mali P, Toppari J, Hakovirta $H$, Lönnerberg P, Ritzén EM, Ebendal T, Olson L, Hökfelt T and Persson H (1992) Expression of B-nerve growth factor and its receptor in rat seminiferous epithelium: specific function at the onset of meiosis Journal of Cell Biology 117 629-641

Peltola V, Huhtaniemi I and Ahotupa M (1995) Abdominal position of the rat testis is associated with high level of lipid peroxidation Biology of Reproduction 53 1146-1150

Pennycuik PR (1967) A comparison of the effects of a range of high temperatures and of two different periods of acclimatization on the reproductive performances of male and female mice Australian Journal of Experimental Biology and Medical Science 45 527-532

Piana GP and Savarese G (1891) Su alcuni studii anatomo-patologici $L a$ Clinica Veterinaria 14 50-51

Plöen L (1972) An electron microscope study of the immediate effects on spermateleosis of a short-term experimental cryptorchidism in the rabbit Virchows Archiv Abteilung B Zellpathologie 10 293-309

Plöen $\mathbf{L}$ (1973a) A light microscope study of the immediate and delayed effects on rabbit spermatogenesis following experimental cryptorchidism for twenty-four hours Virchows Archiv Abteilung B Zellpathologie 10 185-196

Plöen L (1973b) An electron microscope study of the delayed effects on rabbit spermateleosis following experimental cryptorchidism for twenty-four hours Virchows Archiv Abteilung B Zellpathologie 14 159-184

Portmann A (1952) Animal Forms and Patterns Faber and Faber, London

Prabhakar J, Chimbombi M, Malmgren L, Fredriksson G and Madej A (1990) Effects on testosterone and LH concentrations of induced testicular degeneration in bulls Acta Veterinaria Scandinavica 31 505-507

Procopé BJ (1965) Effects of repeated increase of body temperature on human sperm cells International Journal of Fertility 10 333-339

Rafjer J (1982) Endocrinological study of testicular descent in the rabbit Journal of Surgical Research 33 158-163

Rafjer J and Walsh PC (1977) Hormonal regulation of testicular descent, experimental and clinical observations Journal of Urology 118 985-990

Rathore AK (1970) Fertility of rams heated for 1, 2, 3 or 4 days, mated to superovulated ewes Australian journal of Agricultural Research 21 355-358

Ray DE, Roubicek CB and Hamidi M (1968) Organ and gland weights of rats chronically exposed to $22^{\circ}$ and $35^{\circ} \mathrm{C}$ Growth $321-12$

Reid BO, Mason KA, Withers HR and West J (1981) Effects of hyperthermia and radiation on mouse testis stem cells Cancer Research 41 4453-4457

Rhynes WE and Ewing LL (1973) Testicular endocrine function in Hereford bulls exposed to high ambient temperature Endocrinology 92 509-514

Risbridger GP, Kerr JB, Peake R, Rich KA and de Kretser DM (1981) Temporal changes in Leydig cell function after the induction of bilateral cryptorchidism Journal of Reproduction and Fertility 63 415-423

Robinson D and Rock J (1967) Intrascrotal hyperthermia induced by scrotal insulation: effect on spermatogenesis Obstetrics and Gynecology 29 217-223

Rock J and Robinson D (1965) Effect of induced intrascrotal hyperthermia on testicular function in man American Journal of Obstetrics and Gynecology 93 793-801

Rock J, Robinson D and Menkin MF (1968) Control of human spermatogenesis by induced changes of intrascrotal temperature Journal of the American Medical Association 204 290-297 
Rommel SA, Pabst DA, McLellan WA, Mead JG and Potter GW (1992) Anatomical evidence for a counter-current heat exchanger associated with dolphin testes Anatomical Record 232 150-156

Rommel SA, Pabst DA, McLellan WA, Williams TM and Friedl WA (1994) Temperature regulation of the testes of the bottlenose dolphin (Tursiops truncatus): evidence from colonic temperatures Journal of Comparative Physiology B 164 130-134

Rommel SA, Early GA, Matassa KA, Pabst DA and McLellan WA (1995) Venous structures associated with thermoregulation of phocid seal reproductive organs Anatomical Record 243 390-402

Ron-El R, Golan A, Nachum H, Caspi E, Herman A and Soffer Y (1991) Delayed fertilization and poor embryonic development associated with impaired semen quality Fertility and Sterility 55 338-344

Ross AD and Entwistle KW (1979) The effect of scrotal insulation on spermatozoal morphology and the rates of spermatogenesis and epididymal passage of spermatozoa in the bull Theriogenology 11 111-121

Rotter V, Schwartz D, Almon E, Goldfinger N, Kapon A, Meshorer A, Donehower LA and Levine AJ (1993) Mice with reduced levels of p53 protein exhibit the testicular giant-cell degenerative syndrome Proceedings of the National Academy of Sciences USA 90 9075-9079

Ruibal R (1957) The evolution of the scrotum Evolution 11 376-377

Sailer BL, Sarkar LJ, Bjordahl JA, Jost LK and Evenson DP (1997) Effects of heat stress on mouse testicular cells and sperm chromatin structure Journal of Andrology 18 294-301

Sanford LM, Voglmayr JK, Vale WW and Robaire B (1993) Photoperiodmediated increases in serum concentrations of inhibin, follicle-stimulating hormone, and luteinizing hormone are accentuated in adult shortenedscrotum rams without corresponding decreases in testosterone and estradiol Biology of Reproduction 49 365-373

Sarge KD (1995) Male germ cell-specific alteration in temperature set point of the cellular stress response Journal of Biological Chemistry 270 18745-18748

Sarge KD, Park-Sarge OK, Kirby JD, Mayo KE and Morimoto RI (1994) Expression of heat shock factor 2 in mouse testis: potential role as a regulator of heat-shock protein gene expression during spermatogenesis Biology of Reproduction 50 1334-1343

Sarge KD, Bray AE and Goodson ML (1995) Altered stress response in testis Nature 374126

Schwartz D, Goldfinger N and Rotter V (1993) Expression of p53 protein in spermatogenesis is confined to the tetraploid pachytene primary spermatocytes Oncogene 8 1487-1494

Setchell BP (1970) The secretion of fluid by the testes of rats, rams and goats, with some observations on the effect of age, cryptorchidism and hypophysectomy Journal of Reproduction and Fertility 23 79-85

Setchell BP (1978) The Mammatian Testis 450 pp Elek Books, London Cornell University Press, Ithaca

Setchell BP (1994) Possible physiological bases for contraceptive techniques in the male Human Reproduction $91081-1087$

Setchell BP (1997) Sperm counts in semen of farm animals 1932-1995 International journal of Andrology 20209-214

Setchell BP and Mieusset R (1996) Testis thermoregulation. In Male Gametes Production and Quality pp 65-81 Eds S Hamamah and R Mieusset. INSERM, Paris

Setchell BP and Thorburn GD (1969) The effect of local heating on blood flow through the testes of some Australian marsupials Comparative Biochemistry and Physiology 31 675-678

Setchell BP and Thorburn GD (1970) The effect of artificial cryptorchidism on the testis and its blood flow in an Australian marsupial Macropus eugenii. Comparative Biochemistry and Physiology 38 705-708

Setcheil BP and Waites GMH (1972) The effects of local heating of the testis on the flow and composition of rete testis fluid in the rat, with some observations on the effects of age and unilateral castration Journal of Reproduction and Fertility 30 225-233

Setchell BP, Waites GMH and Thorburn GD (1966) Blood flow in the testis of the conscious ram measured with Krypton-85; effects of heat, catecholamines and acetylcholine Circulation Research 18 755-765

Setchell BP, Voglmayr JK and Hinks NT (1971) The effect of local heating on the flow and composition of rete testis fluid in the conscious ram Journal of Reproduction and Fertility 24 81-89

Setchell BP, D'Occhio MJ, Hall MJ, Laurie MS, Tucker MJ and Zupp JL (1988) Is embryonic mortality increased in normal females mated to subfertile males? Journal of Reproduction and Fertility 82 567-574

Setchell BP, Locatelli A, Perreau C, Pisselet C, Fontaine I, Kuntz C, Saumande J, Fontaine J and Hochereau-de Reviers MT (1991) The form and function of the Leydig cells in hypophysectomized rams treated with pituitary extract when spermatogenesis is disrupted by heating the testes Journal of Endocrinology 131 101-112

Setchell BP, Maddocks S and Brooks DE (1994a) Anatomy, vasculature, innervation and fluids of the male reproductive tract. In The Physiology of Reproduction (2nd Edn) pp 1063-1175 Eds E Knobil and JD Neill. Raven Press, New York,

Setchell BP, Zupp JL, Ekpe G, Maddocks S and Grigg G (1994b) The effect of environmental temperature on scrotal temperature in rams at pasture, recorded by telemetry Proceedings of the Australian Society for Reproductive Biology 2687

Setchell BP, Bergh A, Widmark A and Damber JE (1995) Effect of temperature of the testis on vasomotion and blood flow International journal of Andrology $18120-126$

Setchell BP, Tao L and Zupp JL (1996) The penetration of chromium-EDTA from blood plasma into various compartments of rat testes, as an indicator of function of the blood-testis barrier, following exposure of the testes to heat Journal of Reproduction and Fertility 106 125-133

Setchell BP, Ekpe G, Zupp JL and Surani MAH (1998) Transient retardation in embryo growth in normal female mice made pregnant by males whose testes had been heated Human Reproduction 13 342-347

Sharpe RM (1983) Impaired gonadotrophin uptake in vivo by the cryptorchid rat testis Journal of Reproduction and Fertility 67 379-387

Shikone T, Billig H and Hsueh AJW (1994) Experimentally induced cryptorchidism increases apoptosis in rat testis Biology of Reproduction $\mathbf{5 1}$ $865-872$

Sidibe M, Franco LA, Fredriksson G, Madej A and Malmgren L (1992) Effects on testosterone, $\mathrm{LH}$ and cortisol concentrations and on testicular ultrasonographic appearance of induced testicular degeneration in bulls Acta Veterinaria Scandinavica 33 191-196

Sinha Hikim AP, Wang C, Leung A and Swerdloff RS (1995) Involvement of apoptosis in the induction of germ cell degeneration in adult rats after gonadotrophin-releasing hormone antagonist treatment Endocrinology 136 2770-2775

Sinha Hikim AP, Rajavashisth TB, Sinha Hikim I, Lue Y, Bonavera JJ, Leung A, Wang C and Swerdloff RS (1997) Significance of apoptosis in the temporal and stage-specific loss of germ cells in the adult rat after gonadotrophin deprivation Biology of Reproduction 57 1193-1201

Skinner JD and Louw GN (1966) Heat stress and spermatogenesis in Bos indicus and Bos taurus cattle Journal of Applied Physiology 21 1784-1790

Skinner JD and Rowson LEA (1968) Some effects of unilateral cryptorchidism and vasectomy on sexual development of the pubescent ram and bull Journal of Endocrinology 42 311-321

Smith JF (1971) The effect of temperature on characteristics of semen in rams Australian Journal of Agricultural Research 22 481-490

Socher SA, Yin Y, DeWolf WC and Morgentaler A (1997) Temperaturemediated germ cell loss in the testis is associated with altered expression of the cell-cycle regulator p53 Journal of Urology 157 1986-1989

Sod-Moriah UA, Goldberg GM and Bedrak E (1974) Intrascrotal temperature, testicular histology and fertility of heat-acclimatized rats Journal of Reproduction and Fertility 37 263-268

Spencer JR, Torrado T, Sanchez RS, Vaughan ED and Imperato-McGinley J (1991) Effects of flutamide and finasteride on rat testicular descent Endocrinology $129741-748$

Steinberger E and Dixon WJ (1959) Some observations on the effect of heat on the testicular germinal epithelium Fertility and Sterility 10578-595

Stone BA (1981) Heat induced infertility of boars: the inter-relationship between depressed sperm output and fertility and an estimation of the critical air temperature above which sperm output is impaired Animal Reproduction Science 4 283-299

Stone BA and Seamark RF (1984) Effects of acute and chronic testicular hyperthermia on levels of testosterone and corticosteroids in plasma of boars Animal Reproduction Science 7 391-403

Swerdloff RS, Lue YH, Wang C, Rajavashsith T and Sinha Hikim A (1998) Hormonal regulation of germ cell apoptosis. In Germ Cell Development, Division, Disruption and Death pp 151-163 Ed. B Zirkin. Springer Verlag, New York

Thonneau P, Ducot B, Bujan L, Mieusset R and Spira A (1997) Effect of male occupational heat exposure on time to pregnancy International Journal of Andrology 20 274-278

Thwaites CJ, Stapleton DL, Hinch GN and Edey TN (1982) Testicular temperature and sperm production in induced cryptorchid lambs Australian Veterinary fournal 58123 
Tierney LA and Hallford DM (1985) Mating behaviour, serum testosterone and semen characteristics in vasectomized and short scrotum rams Theriogenology $23535-545$

Tokuyama I (1963) Quoted by Leblond CP, Steinberger E and Roosen-Runge EC (1963) Spermatogenesis. In Mechanisms Concerned with Conception pp 1-12 Ed. CG Hartmann. Pergamon Press, Oxford

Turner TT, D'Addario DA, Forrest JB and Howards SS (1982) The effects of experimental cryptorchidism on the entry of $\left[{ }^{3} \mathrm{H}\right]$-inulin and $\left[{ }^{3} \mathrm{H}\right]$ horseradish peroxidase into the lumen of the rat seminiferous tubules Journal of Andrology 3 178-183

Utberg LC and Burfening PJ (1967) Embryo death resulting from adverse environment on spermatozoa or ova Journal of Animal Science 26 571-577

VanDemark NL and Ewing LL (1963) Factors affecting testicular metabolism and function. I. A simplified perfusion technique for short-term maintenance of rabbit testis Journal of Reproduction and Fertility 6 1-8

van der Schoot P (1992) Disturbed testicular descent in the rat after prenatal exposure to the antiandrogen flutamide Journal of Reproduction and Fertility $96483-496$

van Os JL, de Vries MJ, den Daas NH and Lansbergen LMK (1997) Longterm trends in sperm counts in dairy bulls Journal of Andrology 18 725-731

Van Zelst SJ, Zupp JL, Hayman DL and Setchell BP (1995) X-Y dissociation in mice and rats exposed to increased testicular or environmental temperatures Reproduction Fertility and Development 7 1117-1121

Vogler CJ, Saacke RG, Bame JH, DeJarnette and McGilliard ML (1991) Effects of scrotal insulation on viability characteristics of cryopreserved bovine semen Journal of Dairy Science 74 3827-3835

Vogler CJ, Bame JH, DeJarnette JM, McGilliard ML and Saacke RG (1993) Effects of elevated testicular temperature on morphology characteristics of ejaculated spermatozoa in the bovine Theriogenology 40 1207-1219

Voglmayr JK, Setchell BP and White IG (1971) Metabolism and ultrastructure of testicular spermatozoa after local heating of the ram testis Journal of Reproduction and Fertility 24 71-81

Waites GMH and Ortavant R (1968) Effets précoces d'une brève élévation de la température testiculaire sur la spermatogénèse du bélier Annales de Biologie Animale, Biochemie et Biophysique 8323-331

Waites GMH and Setchell BP (1964) Effect of local heating on blood flow and metabolism of the testes of the conscious ram Journal of Reproduction and Fertility $8339-344$

Waites GMH and Setchell BP (1990) Physiology of the mammalian testis. In Marshall's Physiology of Reproduction 4th Edn Vol 2 pp 1-105 Ed. GE Lamming. Churchill Livingstone, London
Waites GMH and Voglmayr JK (1963) The functional activity and control of the apocrine sweat glands of the scrotum of the ram Australain Journal of Agricultural Research 14 839-851

Waites GMH, Quinlan D and Setchell BP (1973) The effect of local heating of the scrotum, testes and epididymides on cardiac output and regional blood flow Journal of Reproduction and Fertility 34 41-49

Waldbieser GC and Chisman CL (1986) X-Y chromosome univalency in the testes of hyperthermic mice: I. Concomitant formation of mutinucleated giant cells Gamete Research 15 153-160

Watanabe A (1959) The effect of heat on human spermatogenesis Kyushu Journal of Medical Sciences 10 101-117

Wensing CJG and Colenbrander B (1986) Normal and abnormal testicular descent Oxford Reviews of Reproductive Biology 8 130-164

Wettemann RP and Desjardins C (1979) Testicular function in boars exposed to elevated ambient temperature Biology of Reproduction 20 235-241

Wettemann RP, Wells ME, Omtveldt IT, Pope CE and Turman EJ (1976) Influence of elevated ambient temperature on reproductive performance of boars Journal of Animal Science 42 664-669

Wettemann RP, Wells ME and Johnson RK (1979) Reproductive characteristics of boars during and after exposure to increased ambient temperature Journal of Animal Science 49 1501-1505

Wildeus $S$ and Entwistle KW (1986) Effects of scrotal insulation and unilateral vasoligation on ejaculate characteristics and sperm reserves in the bull Animal Reproduction Science 10 11-21

Yin Y, Hawkins KL, DeWolf WC and Morgentaler A (1997a) Heat stress causes testicular germ cell apoptosis in adult mice Journal of Andrology 18 159-165

Yin Y, DeWolf WC and Morgentaler A (1997b) p53 is associated with the nuclear envelope in mouse testis Biochemical and Biophysical Research Communications $235689-694$

Yin Y, DeWolf WC and Morgentaler A (1998) Experimental cryptorchidism induces testicular germ cell apoptosis by p53-dependent and -independent pathways in mice Biology of Reproduction $58492-496$

Young WC (1927) The influence of high temperature on the guinea pig testis. Histologic changes and effects on reproduction Journal of Experimental Zoology 49 459-499

Young WC (1929) The influence of high temperature on the reproductive capacity of guinea pig spermatozoa as determined by artificial insemination Physiological Zoology 2 1-8

Zakeri ZF, Welch WJ and Wolgemuth DJ (1990) Characterization and inducibility of hsp 70 proteins in the male mouse germ line Journal of Cell Biology 111 1785-1792 